\title{
Quality of Life and the Migration of the College-Educated: A Life-Course Approach
}

\author{
RONALD L. WHISLER, BRIGITTE S. WALDORF, \\ GORDON F. MULLIGAN, AND DAVID A. PLANE
}

\begin{abstract}
This paper examines how the college-educated population - segmented into selective demographic groups, from young adults to the elderly - differentially values quality-of-life (QOL) indicators of metropolitan areas in the United States. Using data from the 2000 Census and the 1997 Places Rated Almanac, out-migration patterns are shown to depend jointly upon stage in the life course, the spatial-demographic setting, and QOL characteristics. An abundance of cultural and recreational amenities lowers out-migration rates of young college-educated. For the older college-educated population, the revealed preferences shift toward concerns for safety and a strong preference for milder climates. The study also finds significantly lower out-migration rates for metropolitan areas with growing human capital. In light of shifting age distributions and rising educational attainment levels, the results have important implications for the emergence of new migration patterns and the concentration of human capital.
\end{abstract}

\section{Introduction}

$\mathrm{O}$ ne of the most popular rationales for migration is Tiebout's observation that people "vote with their feet." It is now widely recognized that this "migration vote" is contingent on personal characteristics including life-course attributes and on locationspecific characteristics including natural and man-made amenities. Amenities are not measures of overall residential desirability of places, but rather place-specific attributes that people differentially value at different stages of their life. It is also critical to recognize that places offer bundles of amenities: consequently migrants must sometimes take the bad with the good in choosing the place where its set of attributes best satisfies their tastes and preferences.

Ronald L. Whisler is a statistical analyst at The Modellers, LLC, in Salt Lake City, UT. His email address is rwhisler@gmail.com. Brigitte S. Waldorf is a professor in the Department of Agricultural Economics at Purdue University in West Lafayette, Indiana. Gordon F. Mulligan is a professor emeritus and David A. Plane is a professor in the Department of Geography and Regional Development at the University of Arizona in Tucson, Arizona. The authors are grateful to Carmen CarrionFlores, Jacques Poot, and Todd Sorensen for their helpful comments, to Henry W. Herzog, Jr. for his advice on the research design, and to L. Benjamin Luzynski for his assistance with GIS. The authors thank the editor and three anonymous reviewers for their excellent comments and suggestions.

Submitted August 2006; revised June 2007, September 2007; accepted October 2007.

(C) 2008 Blackwell Publishing, 350 Main Street, Malden MA 02148 US and 9600 Garsington Road, Oxford OX4, 2DQ, UK. 
Understanding the interplay of personal characteristics and amenities in migration decisions is pivotal not only because valuations of amenities may differ across life-course groups, but also because of anticipated changes in the composition of the U.S. population. Trends such as the retirement of the baby boomers and the emergence of new demographic groups like the "power couples" (Costa and Kahn 2000) will lead to shifts in the relative importance of different demographic groups. Thus, demographic changes in combination with differential valuations of quality-of-life (QOL) characteristics may trigger substantial shifts in migration patterns and, ultimately, in the nation's population distribution.

To address the joint impact of personal characteristics and amenities on the "migration vote," this paper revisits the seminal U.S. migration study by Herzog and Schlottmann (1986). Their study was particularly important because out-migration patterns from U.S. Metropolitan Statistical Areas (MSAs) were clearly shown to depend both on the characteristics of households and on how those households assessed inter-city differences in QOL indicators. Our research takes the Herzog and Schlottmann study a step further by showing how the valuation of those amenities differs across life-course groups. Toward this end, we use a demographic segmentation approach that allows stratification of our household sample and - as suggested by Cushing (1993) — enables us to estimate separate outmigration models for several life-course groups. To the extent that amenities are differentially valued across life-course groups, migration models estimated without demographic disaggregation are misspecified in positing general effects of various place-specific amenities.

In total, we distinguish between six life-course groups that reflect very different stages in the life course. Age, marital status, and presence of children distinguish these separate demographic groups. Moreover, for each life-course group, we concentrate solely on the migration behavior of the college-educated population. Three reasons justify this selection. First, the college-educated population in the United States has very high migration propensities (Kodrzycki 2001) and is thus one of the most influential driving forces for internal population redistributions. Second, in today's knowledge-based economy, the college-educated constitute the most sought-after segment of the population. A welleducated population positively influences an area's competitiveness and losing the collegeeducated eventually takes a toll on local economies. Thus, understanding the role of amenities - frequently postulated to be the sine qua non for a strong presence of what Florida (2002b) calls the "creative class"-in enhancing a place's retention power is of foremost importance. Finally, from a methodological perspective, a focus on the collegeeducated ensures a certain comparability by income or, at least, by income potential.

The empirical analysis draws on the site-specific amenity scores given in the 1997 Places Rated Almanac and other data on metropolitan attributes and personal characteristics made available from the 2000 U.S. Census. For each life-course group, out-migration propensities are specified as a function of amenity scores and a series of control variables. A logit framework is used for estimation.

The paper is organized as follows. In the next section, we provide a brief overview of the literature connecting amenities, life cycle, and migration. The third section revisits and 
updates the important Herzog and Schlottmann (1986) study. The fourth section describes the research design, paying special attention to the QOL variables, the stratification of the six life-course groups, and the model specification. The empirical results are presented in the fifth section. The paper concludes with a summary of findings and future research directions.

\section{Previous Research}

This study was informed by several overlapping research streams. One of these was the literature devoted to the postindustrial landscape, where analysts have increasingly recognized the role played by amenities or QOL factors in the location decisions of households and firms (Dissart and Deller 2000; Mulligan, Carruthers, and Cahill 2004). Other ideas were drawn from the very wide literature on household migration, where some analysts prefer to assess aggregate movements of people while others identify those diverse factors accounting for the choices made by individual movers (Greenwood 1975; Greenwood, Mueser, et al. 1991). A third research stream focuses more on the decision-making of the household and attempts to uncover those internal attributes and external forces that dictate behavioral change at certain key points in the life course (Golledge and Stimson 1997). Finally, the study is embedded in the quickly growing literature on locational decisions and spatial concentrations of the highly educated population (Adamson, Clark, and Partridge 2004; Gottlieb and Joseph 2006).

Amenities. Amenities are site- or region-specific goods and services that make localities more or less attractive to agents. They enter into the consumption decisions of households and the production decisions of firms, and therefore, play an important role in the location choices of these agents (Diamond and Tolley 1982). Amenities first became of wide interest with the emergence of postindustrialism (Bell 1973), particularly in the United States (Berry and Horton 1970). They were originally considered to be largely natural but now man-made amenities and disamenities are of greater interest for reasons of public policy (Carruthers and Mundy 2006). Today, there is widespread recognition that man-made amenities affect both the level and the distribution of society's scarce resources through spatial externalities (Smith 1977), a geographic fact that is now seen most clearly in the world's very largest cities (Scott 2001).

Much research is driven by the notion of compensating differentials, which follows from Rosen (1974) and Roback (1982). Here location-specific amenities work through both labor and land markets, so representative households can be indifferent between living in attractive (low wages, high rents) versus unattractive places (high wages, low rents). Among large metropolitan areas, this compensation process appears to work at both interand intra-regional levels, as evidenced by Bloomquist, Berger, and Hoehn (1988). Research has extended compensating differentials to local fiscal conditions as well and well-managed local governments affect the behavior of firms and households much like valued environmental amenities (Gyourko and Tracy 1991). In more recent times, people like Glaeser (1999), Costa and Kahn (2000), and Florida (2002a) have argued that young, well-educated households have strong preferences for certain kinds of urban milieus in order to satisfy 
their lifestyle demands and maximize their life chances. Invariably, these milieus include, but are not restricted to, the following list of attributes: wide variety in consumer goods and services; diverse entertainment and recreational possibilities; dense networks of educational, employment, and social opportunities; and tolerant racial and social attitudes.

Migration. Migration is the location adjustment made by households in response to their ever-changing needs and preferences. In the United States, some 15 to 20 percent of the population change their residence every year, suggesting a nation that is perpetually reallocating its human resources in space as some places (e.g., neighborhoods and regions) rise and others decline.

The reasons for these moves are diverse. Relocation occurs in those situations where in situ adjustments fail to bring down high levels of stress to tolerable levels (Brown and Moore 1970; Wolpert 1965). Aggregate models of this behavior typically include two types of attributes: those that either repel households from one place or attract them to another and those that affect the ease of movement between those places. From a human capital perspective (Sjaastad 1962), migration is one of several means by which a household can improve its life chances. Here the household calculates the present value of place-specific benefits and the various costs of moving to other places before deciding on staying or moving. Finally, neoclassical theories of regional growth argue that households move in response to wage-rate differences, although the interregional gap between nominal and real wages can vary significantly depending upon the geography of amenities. But here it is difficult to gauge the quality of information that households have about such matters as job openings, housing vacancies, and education opportunities at other locations, all factors that can severely inhibit the movement of households to those alternative destinations (Isserman 1986).

Neoclassical migration models were devised during the industrial era when workers tended to move from low-wage areas with labor surpluses to high-wage areas with labor shortages (Borts and Stein 1964). This disequilibrium model suggests that regional wages equilibrate over the long run although some observers pointed out that migration tends to be both circular and selective (Greenwood 1973; Thirlwall 1966). In any case, (spatial) equilibrium models have been more popular in recent times. As in urban hedonic models, household behavior is seen to be strongly affected by the geography of amenities and disamenities, so that nominal differences in wages between labor markets, even when they are fairly substantial, do not necessarily lead to migration.

This approach was pioneered by Graves (1979, 1980, 1983), along with Graves and Linneman (1979), and a flood of later studies repeatedly has confirmed the influence of amenities on migration (e.g., Clark and Hunter 1992; Clark, Knapp, and White 1996; Clark, Lloyd, and Jain 2002; Porell 1982; Rappaport 2007). The demand for place-specific amenities has price and income effects just like any other good or service, and localized shifts in demand can be initiated by age, gender, and race changes in the local population. For this paper, a couple of findings are especially worthy of note. First, the approach strongly endorses the importance of life cycle in hedonic migration research. Clearly, a natural amenity like winter warmth is valued by retirees as a normal good while a disamenity like humidity is valued as an inferior good. Second, significant behavioral 
differences exist across subpopulations depending upon the resources they can access. Winter warmth might be valued as a superior good by richer households but only as a normal good by poorer households. Man-made amenities like public education and disamenities like crime presumably exhibit the same sorts of price and income effects (Porell 1982).

Related work by Clark and Hunter (1992) has indicated that the disequilibrium approach clearly loses its explanatory ability for older-age cohorts who increasingly value QOL factors as they approach retirement age. Other research by Greenwood, Hunt, et al. (1991) and Mueser and Graves (1995) has sought to reconcile the disequilibrium and equilibrium approaches over a lengthy time interval, finding that in some periods, firm profit was dominant in driving job-related migration while in other periods, household utility was dominant in driving amenity-related migration. In any case, this line of research indicates that an appreciation of the demographic makeup and socio-economic composition of each region's population is not only critical for assessing how jobs and amenities are differentially valued in those regions, but is also very important for understanding the nature of household movement that takes place between those regions.

Life course. In demography, sociology, and geography, household life-cycle models have been popular for decades in migration studies and in the social area analysis of large metropolitan areas (Berry and Horton 1970). Today, there is no doubt that stage in the household life cycle is one of the main determinants of residential relocation in the advanced economies. The postindustrial improvements in health and longevity have other important economic implications worthy of note. First, as Becker (1993) pointed out, people now have a greater incentive to invest in human capital because they can enjoy the benefits over a longer period of time. This means that individuals have probably become more rational about when and where they actually decide to carry out this investment, whether they choose deepening their skills or furthering their education. Second, postindustrial households occupy more life-course stages than their industrial predecessors and their longitudinal consumption patterns now change a lot as they pass through life's recognizable stages. Indeed, Wakabayashi and Hewings (2007) provide recent evidence of this from Japan, where they suggest that such changes in consumption behavior have important implications for structural change in postindustrial economies. Moreover, their data indicate that significant regional variation exists in the budget shares of households, a finding that confirms that entire regions can have very different aggregate consumption profiles. An implication of this is that households will relocate-at certain strategic times - from one region to another in order to take advantage of the place-specific consumption opportunities that are more available in that other region.

The sociologist Rossi's (1955) work was important for connecting the household's life-cycle stages to its preferences and needs for housing. In subsequent work, the term life course often has been substituted, apparently to avoid age and structural stereotypes during this era of postindustrialism (Levinson 1978). Some observers have suggested as many as ten different life-cycle events that are related to residential adjustment or relocation (Rowland 1982). Completion of tertiary education, marriage, and retirement are widely 
acknowledged to be three of the most important events in the life course, although it is acknowledged that the life-cycle factor is a useful predictor of relocation only when it is combined with other lifestyle and socio-economic information about the household.

There certainly exists a wealth of studies addressing the issue of age-dependency in migration, a notion that is perhaps most succinctly captured in the concept of migration age schedules (Pandit 1997; Rogers 1988). The dependency of migration on life-course events has been highlighted in a recent study by Plane and Heins (2003), who identified seven age cohorts based on characteristic migration patterns. In other words, knowledge of the origins and destinations of migration streams provides some clues by itself to the life-course attributes of the households that are actually involved in moving. In addition to age, marital status is an important descriptor of the life course influencing migration behavior. The seminal work by Mincer (1978), complemented by the studies of Graves and Linneman (1979) and Schaeffer (1987), emphasize the reduced migration propensities of married compared to nonmarried persons. More recent studies (e.g., Jürges 2006; Nivalainen 2004; Swain and Garasky 2007) continue to emphasize the importance of marital status, often in combination with gender roles.

Understanding the joint influence of differential valuation of place attributes across the life course is even more important when considering the migration patterns of the collegeeducated. Their high income potential imposes fewer constraints on relocating according to tastes and preferences. However, the literature has not yet addressed this issue in adequate detail. Instead, research on the locational choices of the highly educated focuses either on the young as a special group (e.g., Franklin 2003; Gottlieb and Joseph 2006) or on the entire college-educated workforce (e.g., Waldorf 2007).

What we do know with certainty is that the highly educated population is a particularly mobile group. Basker (2002) reports that persons with at least a bachelor's degree now account for 37 percent of all migrants but they comprise only 27 percent of the population. The highly educated also have very distinct migration patterns. Kodrzycki (2001), for instance, finds that the college-educated population is disproportionately likely to engage in long-distance moves. Thirty percent of graduates no longer live in the state where they attended college, and an even greater percentage no longer live in the state where they completed high school. These percentages far exceed the figures for those who never graduated from college. Recent research by Wilkinson (2007) further shows that the college-educated are less likely than those with lower levels of educational attainment to move downward within the urban hierarchy. There is also evidence that the collegeeducated population itself becomes an amenity that attracts other well-educated migrants. Waldorf (2007) finds that highly educated migrants are disproportionately attracted by the high educational status of current residents, while Gottlieb and Joseph (2006) find that science and technology graduates are especially prone to move to those places having better-educated populations. If these selective migration behaviors continue over a prolonged time period, the spatial distribution of the highly educated population will become increasingly concentrated, possibly creating striking disparities between brain-rich and brain-poor regions. 


\section{GROWTH AND CHANGE, MARCH 2008}

Equally important, the literature also contends that human capital propels regional economic growth (Mathur 1999), where many observers argue that amenities play a prominent role in attracting the college-educated workforce (Florida 2000a,b; Glaeser, Kolko, and Saiz 2000). Recently, Gottlieb and Joseph (2006) find that Ph.D. graduates are particularly responsive to amenities when making their locational choices. Clark, Lloyd, and Jain (2002) even argue that for the college-educated workforce, "the decision about where to live and enjoy life can play as large or a larger role than the job offer itself in the final location decision" (p. 513). While, in general, amenities and their power to attract the highly educated are increasingly viewed as the new driving force of urban and regional growth, little is known about how amenity valuations of the highly educated may differ across the various stages of the life course.

\section{Updating Herzog and Schlottmann (1986)}

Herzog and Schlottmann analyzed individual responses to macro site-specific amenity data, estimating a binary logit model of leaving versus staying in a MSAs. The sample was restricted to employed individuals between the ages of twenty-three and sixty, who were living in their state of birth in 1975, not attending college, and not serving in the military.

The dependent variable was proxied using the 1980 U.S. Census 1 percent Public-Use Microdata Sample (PUMS) data on residential location in 1975 and in 1980. Categorized as movers were individuals who, in 1980, resided anywhere outside the MSAs in which they resided in 1975. Personal attributes - age, race, gender, marital status, presence of children, and years of education-were obtained from the 1980 U.S. Census 1 percent PUMS data. Information on place-specific attributes was taken from the 1981 Places Rated Almanac, where amenity scores were generated to describe metropolitan variations in living costs, transportation, job opportunities, education, climate, crime, the arts, health care, and recreation.

We updated the Herzog and Schlottmann (1986) model using the 1997 Places Rated Almanac and the 2000 U.S. Census 5 percent PUMS. Table 1 shows the results originally presented by Herzog and Schlottmann and the updated results. Both studies similarly suggest that people tend to leave metropolitan areas with high costs of living and high crime rates, whereas rich recreational opportunities dampen out-migration propensities. In the late 1990s, just like twenty years earlier, we find low propensities to migrate for AfricanAmericans, older persons, poorly educated persons, and households with children. Neither gender nor marital status has a significant influence on migration propensities in either time period.

However, there are also important differences. Unlike in the 1975-1980 time period, out-migration propensities for 1995-2000 are higher for areas with a poor job outlook and a deprived cultural environment, whereas counterintuitive signs are found for the education and climate variables. The updated model suggests that people are prone to leaving metro areas with a wealth of educational opportunities and an agreeable climate. These counterintuitive findings may simply reflect high out-migration from fast-growing metro areas 
Table 1. Updated and Original Parameter Estimates of the Herzog and SCHLOTTMANN (1986) MODEL.

\begin{tabular}{lcc}
\hline & Updated & Original \\
\hline Constant & $-0.374594^{* *}$ & -0.8338 \\
Economic and quality-of-life variables & & \\
$\quad$ Housing (cost of living) & & \\
Economics (job outlook) & $-0.002790^{\star * * *}$ & $0.0752^{\text {b**}}$ \\
Climate & $-0.000851^{* *}$ & 0.0442 \\
Recreation & $0.002510^{* * *}$ & -0.2503 \\
Arts & $-0.005760^{* * *}$ & $-0.2992^{* *}$ \\
Education & $-0.003720^{* * *}$ & $0.0166^{*}$ \\
Health care & $0.002510^{* *}$ & -0.2566 \\
Transportation & 0.000543 & -0.0769 \\
Crime & -0.001320 & -0.0200 \\
Personal characteristics & $-0.001880^{* * *}$ & $0.2960^{* *}$ \\
Black & & \\
Age & $-0.565349^{* * *}$ & $-0.8035^{* * *}$ \\
Female & $-0.062758^{* * *}$ & $-0.0582^{* * *}$ \\
Married & -0.045036 & -0.1686 \\
Education attainment & 0.032832 & -0.1288 \\
Children & $0.123125^{* * *}$ & $0.0944^{* * *}$ \\
$n$ & $-0.509338^{* * *}$ & $-0.2158^{* *}$ \\
\# leaving & 49,920 & 7,426 \\
\% leaving & 6,511 & 761 \\
\hline
\end{tabular}

${ }^{*} \mathrm{p}<.10 ;{ }^{* *} \mathrm{p}<.05 ;{ }^{* * *} \mathrm{p}<.01$.

a The 1981 Almanac data included a score for housing costs. In the 1997 data, the housing costs score is substituted with a broader cost-of-living score that includes housing costs. For the cost-of-living score, high values indicate affordability (i.e., low costs). Thus, although the signs of the estimates differ across the two studies, both suggest that people leave high-cost areas at a higher rate than low-cost areas.

b The 1997 Placed Rate Almanac used "Job Outlook" instead of "Economics."

${ }^{c}$ In the earlier data, low crime scores are indicative of low crime rates. In the 1997 data, the opposite is true. Thus, despite the differing signs, both studies suggest that migration propensities increase with increasing crime rates.

with high in-migration rates. They might also be explainable if QOL amenities are, in fact, valued differently across life-course groups.

Herzog and Schlottmann applied the estimated parameters to U.S. metropolitan areas to rank them by out-migration rates. Table 2 shows the fifty metro areas with the lowest 
TABlE 2. Fifty MSAS With THE LOWESt OUt-MigRATION RATES DERIVED FROM THE Updated, Original Herzog and Schlottmann (1986) Model (Metro AREAS IN ALPHABETICAL ORDER).

\begin{tabular}{|c|c|c|}
\hline $\begin{array}{l}\text { Original and } \\
\text { updated model }\end{array}$ & Original model only & Updated model only \\
\hline Albany-Schenectady, NY & Asheville, NC & Akron, $\mathrm{OH}$ \\
\hline Appleton-Oshkosh, WI & Billings, MT & Atlanta, GA \\
\hline Buffalo-Niagara Falls, NY & Binghamton, NY & Barnstable-Yarmouth, MA \\
\hline Chicago, IL & Boston, MA & Benton Harbor, MI \\
\hline Cincinnati, $\mathrm{OH}$ & $\begin{array}{l}\text { Brownsville- } \\
\text { Harlingen, TX }\end{array}$ & Biloxi-Gulfport, MS \\
\hline $\begin{array}{l}\text { Cleveland-Lorain-Elyria, } \\
\text { OH }\end{array}$ & Cedar Rapids, IA & Denver, CO \\
\hline Dallas, TX & Eau Claire, WI & Detroit, MI \\
\hline Duluth-Superior, MN-WI & Elmira, NY & Glens Falls, NY \\
\hline Erie, PA & Evansville, IN & Hartford, CT \\
\hline Fort Wayne, IN & Grand Forks, ND & Houma, LA \\
\hline Fort Worth, TX & Green Bay, WI & Houston, TX \\
\hline $\begin{array}{l}\text { Grand Rapids-Muskegon, } \\
\text { MI }\end{array}$ & $\begin{array}{l}\text { Greensboro-Winston- } \\
\text { Salem, NC }\end{array}$ & Indianapolis, IN \\
\hline Milwaukee-Waukesha, WI & Johnstown, PA & Jamestown, NY \\
\hline Minneapolis-St. Paul, MN & Kenosha, WI & Kalamazoo-Battle Creek, MI \\
\hline Nassau-Suffolk, NY & La Crosse, WI & Kansas City, MO \\
\hline Pittsburgh, PA & $\begin{array}{l}\text { Lansing-East } \\
\text { Lansing, MI }\end{array}$ & Knoxville, TN \\
\hline Rochester, NY & Madison, WI & Las Vegas, NV \\
\hline St. Louis, MO & $\begin{array}{l}\text { McAllen-Pharr- } \\
\text { Edinburg, TX }\end{array}$ & Monmouth-Ocean, NJ \\
\hline \multirow[t]{9}{*}{ Syracuse, NY } & New Bedford, MA & New Orleans, LA \\
\hline & Odessa, TX & Norfolk-Virginia Beach, VA \\
\hline & $\begin{array}{l}\text { Parkersburg-Marietta, } \\
\text { WV-OH }\end{array}$ & Omaha, NE \\
\hline & Pittsfield, MA & Orlando, FL \\
\hline & Racine, WI & Philadelphia, PA-NJ \\
\hline & $\begin{array}{l}\text { Scranton-Wilkes- } \\
\text { Barre, PA }\end{array}$ & Provo-Orem, UT \\
\hline & Seattle-Everett, WA & Richmond-Petersburg, VA \\
\hline & Sioux Falls, SD & Salt Lake City-Ogden, UT \\
\hline & St. Cloud, MN & Sheboygan, WI \\
\hline
\end{tabular}


TABLE 2. (CONTINUED)

\begin{tabular}{lll}
\hline $\begin{array}{l}\text { Original and } \\
\text { updated model }\end{array}$ & Original model only & \multicolumn{1}{c}{ Updated model only } \\
\hline & Steubenville-Weirton, \\
OH-WV & Tampa-St. Petersburg, FL \\
Terre Haute, IN & Tulsa, OK \\
Utica-Rome, NY & Washington, DC-MD-VA \\
Wheeling, WV & Youngstown-Warren, OH \\
Wichita, KS & \\
\hline
\end{tabular}

out-migration rates derived from the original and from the updated model. In the late 1970s, metro areas in the Middle Atlantic and Midwest had the lowest out-migration rates. Twenty years later, the set of fifty metro areas with low out-migration rates overlaps quite a bit with the set identified for the late 1970 s, with eighteen of the fifty metro areas appearing in both lists. ${ }^{1}$ However, using the 2000 data, we find that many metro areas located in the South and Mountain West have entered the top fifty list, including Atlanta, Denver, Las Vegas, Orlando, Salt Lake City, and Tampa-St. Petersburg. The significant parameter estimates of the updated model found in Table 1 indicate that this can be largely attributed to affordable cost of living, low crime rates, and good access to educational and recreation opportunities. Whereas much of the focus has been on in-migration to such areas, these results suggest that part of their population growth can be attributed to their retention ability.

While the results shown in Tables 1 and 2 are in general quite insightful, the models cannot address possible differential valuation of amenities nor situate out-migration propensities within metro areas' demographic profiles. We next extended our analysis to address these shortcomings.

\section{Research Design}

Model. A discrete-choice binary logit model is used to analyze the effects of amenities on the decision to leave a metropolitan area. As in the Herzog and Schlottmann (1986) model, the dichotomous choice being analyzed is whether or not a person migrated out of the metropolitan area and the exogenous variables include the 1997 Places Rated Almanac scores for the place of origin. However, our modeling framework differs in three important ways from that of Herzog and Schlottmann. First, we include control variables that address contextual differences between metropolitan areas such as population size, density, and net migration. Second, our model is estimated separately for six different life-course groups of the college-educated population. Finally, we lifted the birthplace restriction. That is, two regimes were specified that represent, respectively, persons born within the same state as their 1995 MSA of residence and persons born in a different state. The estimations allow for possible differences in the valuation of amenities by place of birth. 
Sample. The 2000 Census 5 percent PUMS data include information on householders' age, marital status, educational attainment, employment status, presence of children, and residential locations in 1995 and 2000. This information is used to define the broad population at risk of migrating, namely all householders who, in 2000, had at least a bachelor's degree, lived anywhere in the United States (metro or nonmetro area) and who, in 1995, resided in a metropolitan area. ${ }^{2}$ We followed the lead of Herzog and Schlottmann by excluding householders who are 1) under 65 and unemployed, 2) over 64 and employed, 3) not born in the United States, 4) serving in the military in 2000, and 5) not living in a housing unit in 2000 .

Sample segmentation. The sample of college-educated persons is segmented into six groups that reflect distinctive stages of the life course. ${ }^{3}$ The groups are defined by marital status, age, presence of children, and employment status (Table 3). ${ }^{4,5}$ Recent graduates are employed, between the ages of twenty-four and twenty-eight in 2000, have never been married, and have no children. Their moves between 1995 and 2000 represent the collegeto-work migration. The group is split by gender to allow for gender gaps in migration behavior. The group of young marrieds consists of married childless householders between the ages twenty-nine and thirty-three. There is no gender distinction because people in this group are married and presumed to move jointly, where either spouse could have been listed as the householder. The numerically largest group, the settled-down middle-agers, consists of people between ages thirty-four and fifty-four. They have at least one child and are married. The about-to-retire empty-nesters group includes persons between the ages fiftyfive and sixty-four in 2000. They are married but do not have any children living with them; it is unknown if earlier in life their households included children. Finally, the group of retired empty-nesters consists of people between the ages sixty-five and eighty-five, who are not in the labor force, and are married without children living at home.

Variable definitions and hypothesized effects. The list of variables, their sources, and definitions are summarized in Table 4. The dependent variable, derived from 2000 PUMS data on residential location in 1995 and 2000, takes the value of 1 ("mover") if the 1995 MSA of residence is different from the 2000 residence and the value of 0 ("stayer") otherwise. ${ }^{6}$

The location-specific scores from the 1997 Places Rated Almanac are the key explanatory variables. MSAs are rated on nine factors believed to influence the quality of a place: cost of living, job outlook, climate, recreation, the arts, health care, education, transportation, and crime (Savageau and Loftus 1997). Despite its primarily nonscientific purpose, the Places Rated Almanac has been widely used in QOL research (Florida 2002a; Rappaport 2003). Moreover, following some criticism (see Landis and Sawicki 1988) ${ }^{7}$ of the earlier editions, the Places Rated Almanac methodology has undergone some modification over the years.

The cost-of-living score in the Almanac is determined by nine categories that account for most expenditures of a "typical" four-person household. It is probably the most controversial and trickiest to interpret because of its broad range of inputs. In particular, the housing-cost component, which accounts for 25 percent of the score, is problematic. Previous work has shown that places with comparative production advantages not 


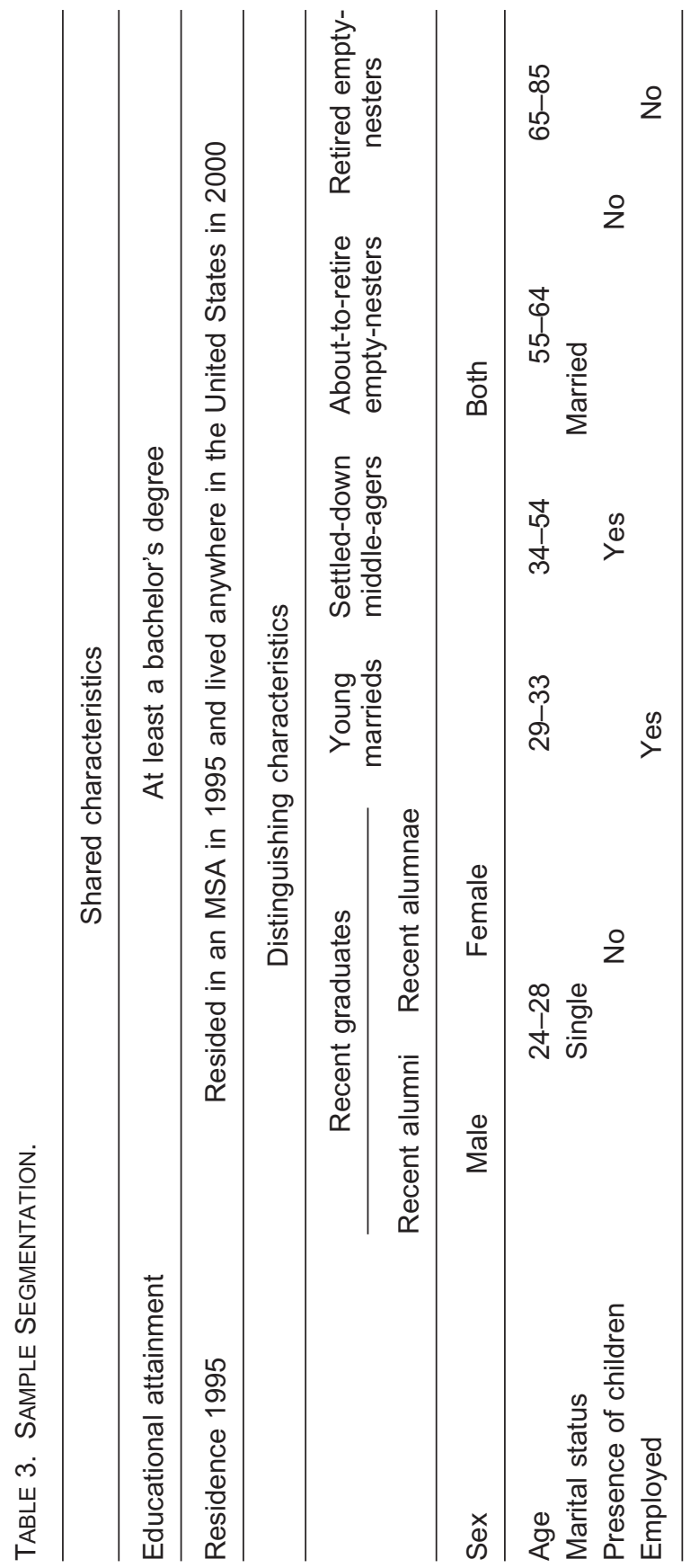


TABle 4. VARiable Definitions And Sources.

\begin{tabular}{|c|c|c|}
\hline Variable & Definition & Source \\
\hline \multicolumn{3}{|c|}{ Dependent variable } \\
\hline Mover & $\begin{aligned}= & 1 \text { if } 1995 \mathrm{MSA} \text { of residence differs from } \\
& 2000 \text { residence } \\
= & 0 \text { otherwise }\end{aligned}$ & 2000 5\% PUMS \\
\hline \multicolumn{3}{|c|}{ Exogenous variables } \\
\hline Cost of living & $\begin{array}{l}\text { Components (weights): mortgage }(25.3 \%) \text {; } \\
\text { transportation }(21.3 \%) \text {; food }(19.8 \%) ; \\
\text { healthcare }(9.3 \%) \text {; utilities }(8.9 \%) \text {; other } \\
\text { expenditures }(6.9 \%) \text {; income tax }(4.1 \%) \text {; } \\
\text { property tax }(3.2 \%) \text {; sales tax }(1.2 \%)\end{array}$ & $\begin{array}{l}1997 \text { Places } \\
\text { Rated Almanac }\end{array}$ \\
\hline Job outlook & $\begin{array}{l}\text { Components (weights): increase in number } \\
\text { of new jobs }(74 \%) \text {; percentage increase } \\
\text { of new jobs }(26 \%)\end{array}$ & \\
\hline Transportation & $\begin{array}{l}\text { Components (weights): connectivity }(60 \%) \text {; } \\
\text { commute }(30 \%) ; \text { centrality }(10 \%)\end{array}$ & \\
\hline Education & $\begin{array}{l}\text { Components (weights): two-year institutions } \\
\text { enrollment (9.5\%); bachelor's degree } \\
\text { institutions enrollment (19\%); } \\
\text { comprehensive institutions enrollment } \\
\text { (28.6\%); doctoral degree institutions } \\
\text { enrollment }(42.9 \%)\end{array}$ & \\
\hline Health & $\begin{array}{l}\text { Components (weights unavailable): } \\
\text { general/family practitioners per capita; } \\
\text { medical specialists per capita; surgical } \\
\text { specialists per capita; accredited general } \\
\text { hospital beds per capita; medical student } \\
\text { enrollment per capita }\end{array}$ & \\
\hline Crime & $\begin{array}{l}\text { Components (weights): violent crime rate } \\
(90.9 \%) ; \text { property crime rate }(9.1 \%)\end{array}$ & \\
\hline Arts & $\begin{array}{l}\text { Components (weights unavailable): } \\
\text { bigness—sheer number of cultural } \\
\text { activities; reading popularity; museum } \\
\text { popularity }\end{array}$ & \\
\hline Recreation & $\begin{array}{l}\text { Components (weights): bigness—sheer } \\
\text { number of recreation activities }(60 \%) ; \\
\text { recreation land }(22 \%) \text {; golf, movies, good } \\
\text { food per capita }(18 \%)\end{array}$ & \\
\hline
\end{tabular}


TABLE 4. (CONTINUED)

\begin{tabular}{|c|c|c|}
\hline Variable & Definition & Source \\
\hline Climate & $\begin{array}{l}\text { Components (weights): mildness }(72 \%) \text {; } \\
\text { brightness }(16 \%) \text {; stability }(12 \%)\end{array}$ & \\
\hline $\begin{array}{l}\text { Population } \\
\text { size }\end{array}$ & MSA's population size in 2000 & $\begin{array}{l}\text { U.S. Census } \\
2000\end{array}$ \\
\hline Density & MSA's population per square mile in 2000 & \\
\hline Net migration & Net migration rate between 1995 and 2000 & \\
\hline $\begin{array}{l}\text { Human capital } \\
\text { growth }\end{array}$ & $\begin{array}{l}\text { Percentage change of college educated } \\
\text { persons between } 1990 \text { and } 2000\end{array}$ & $\begin{array}{l}\text { U.S. Census } \\
1990 \text { and } 2000\end{array}$ \\
\hline Mile50 & $\begin{array}{l}\text { Number of metropolitan areas within a } \\
50 \text {-mile radius of the metro area of } \\
\text { residence }\end{array}$ & $\begin{array}{l}\text { OMB, } 1999 \text { MSA } \\
\text { Boundaries }\end{array}$ \\
\hline
\end{tabular}

only have higher housing costs but also higher wages (Roback 1982). Moreover, amenities - including the man-made variety - are capitalized in housing values and rents (Bloomquist, Berger, and Hoehn 1988; Welch, Carruthers, and Waldorf 2007).

The Almanac's job outlook factor describes the short-term expectation for job growth between 1997 and 2000. It is simply a projection of aggregate job growth and does not account for the MSA's industry mix of employment. The climate score assigns places with mild, sunny, and stable conditions better ratings than places with extreme, cloudy, or unstable conditions. The recreation score assesses the availability of popular recreational activities, popular leisure activities, and the quality of restaurants. The arts, health care, and education dimensions capture the incidence of cultural amenities, the availability of health professionals, and the existence of local higher-education opportunities, respectively. However, the scores do not account for any inter-metropolitan differences in quality, expense, or accessibility. While the education score certainly reflects the variety of higher education options, it does not adequately assess the quality of local schools or colleges. Moreover, the proprietary nature of the data means that the weighting methodologies of the Almanac are not always transparent to the reader. The transportation score describes the efficiency of local transportation infrastructure, the availability of public transportation, and the degree of connectivity to various national transportation grids. The crime score describes the prevalence of property and violent crime. Because the impact on victims differs across these two types of crime, violent crime is weighted ten times more heavily than property crime.

For all nine factors, the scores range on a continuous scale from zero to one hundred and are standardized such that the 50th percentile point is the average score of all MSAs (Savageau and Loftus 1997). Low scores signal strong disamenities: that is, lack of opportunities in recreation, the arts, education, and health care; poor transportation services; poor climate; high crime rates; and high cost of living. Table 5 summarizes the 
72 GROWTH AND CHANGE, MARCH 2008

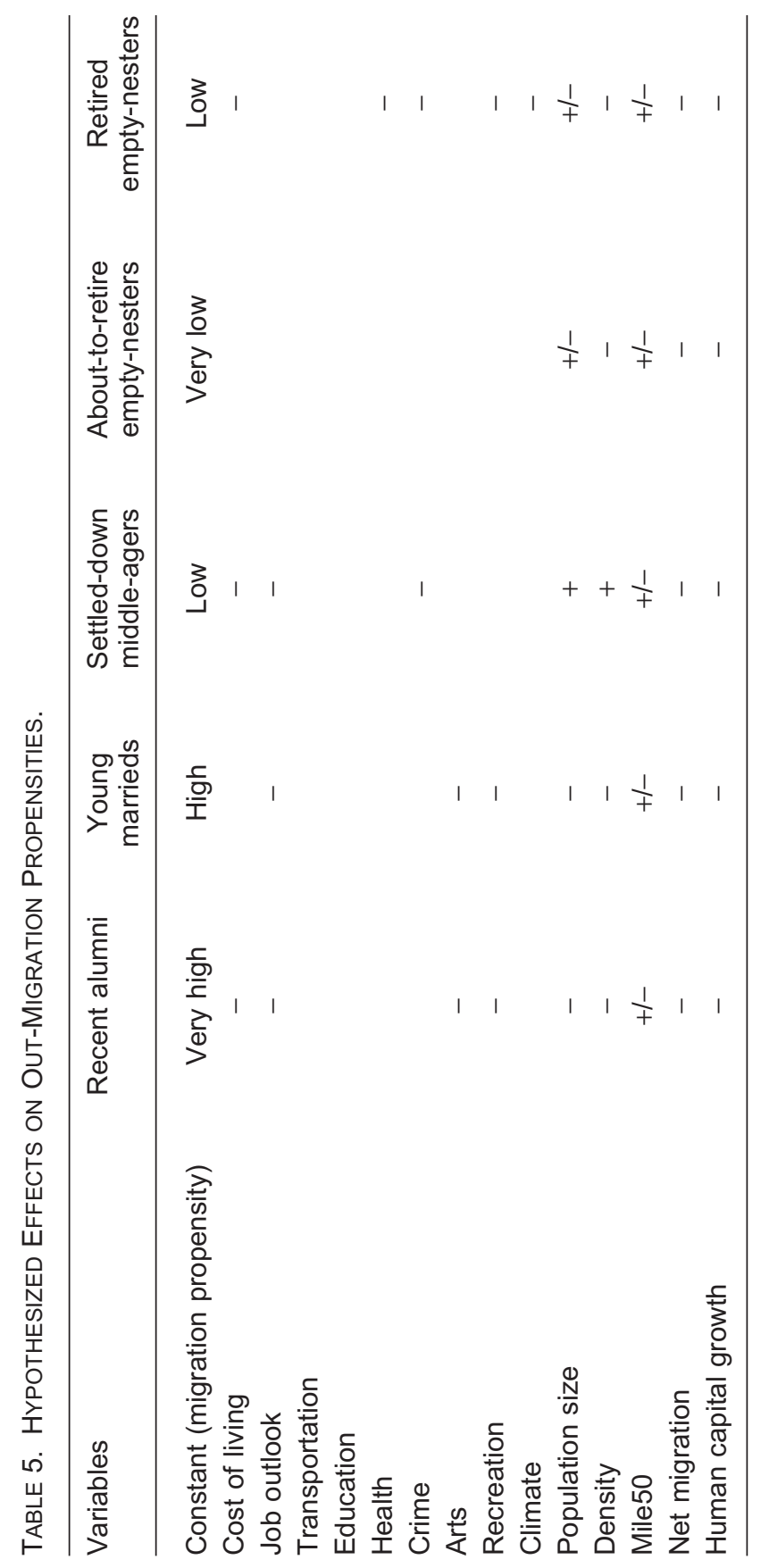


hypothesized effects of the QOL variables on migration propensities for each of the six demographic segments. A negative effect on migration indicates that the absence or weakness of an amenity serves as a push factor of migration.

For recent graduates, finding a good, permanent job is hypothesized to be the most important factor. Because these persons are at the beginning of their careers and may be burdened by student loans, high cost of living is also hypothesized to be a push factor. Moreover, they are expected to highly value recreation and the arts. The young marrieds have already started a career, may enjoy a sizeable discretionary income, and can migrate for career advancement without being tied down by children. Just like the recent graduates, we expect them to be more likely to leave MSAs with low scores on the job outlook, recreation, and arts factors, yet be less concerned about cost of living. Settled-down middle-agers with children are expected to highly value family-friendly environments. Safety concerns among this group are hypothesized to raise out-migration from MSAs with low crime scores (i.e., high crime rates). To offset the high cost of raising children, they are expected to leave expensive MSAs. For the about-to-retire empty-nesters, no a priori expectations are specified other than that their migration propensity is the lowest among the six groups. Many in this group are likely to retire soon, and relocation decisions are likely to be postponed until retirement. Finally, the retired empty-nesters do not have mobility restrictions associated with employment or children. We expect that high cost of living, high crime rates, and adverse climates are significant push factors for this group. In addition, we hypothesize that this older population group values good health care and thus has high out-migration rates in those MSAs with poor scores on the health care factor.

The model also includes contextual factors that situate out-migration decisions within the overall spatial-demographic context. Such controls are necessary because out- and in-migration rates tend to be positively correlated, at least in the aggregate, ${ }^{8}$ and outmigration rates are often highly correlated with places' overall population growth and economic prosperity (Beale 1969; Gleave and Cordey-Hayes 1977; Lowry 1966; Plane, Rogerson, and Rosen 1984). Thus, without consideration of the spatial-demographic context, estimated out-migration propensities cannot be used to make statements about population change and can certainly not be interpreted as an indicator for a metro area's desirability.

Five variables are used to describe the spatial-demographic context. Population size and density control for the wealth of opportunities within the metropolitan area. Residents of small and low-density metro areas may not easily find alternative employment or housing locally. They, therefore, may be more inclined to leave a metropolitan area. Both variables are thus hypothesized to have a negative effect on out-migration propensities of the young groups interested in starting or advancing their careers.

The distance variable Mile50 - indicating the number of metropolitan areas within a fifty-mile radius - allows us to differentiate between metro areas that are part of a larger urban agglomeration, for example, those along the East Coast, and metro areas that have a large rural hinterland, for example, those in the Great Plains. We do not have a prior expectation about the net direction of the effect. On the one hand, it may be that remotely 


\section{GROWTH AND CHANGE, MARCH 2008}

located metro areas record low out-migration rates because every inter-metropolitan move implies that it be a long-distance move. On the other hand, in metro areas that are surrounded by other metro areas, out-migration rates may also be low because commuting may serve as a substitute for migration.

The net migration variable controls whether a metropolitan area gains or loses through migration. It differentiates between, for example, Denver and Buffalo. In Denver, low out-migration rates are part of an overall growing demographic setting whereas in Buffalo they are part of a stagnating demography. Finally, the variable human capital growth indicates changes in the share of the college-educated population. We have witnessed increasing spatial concentrations of the college-educated population, epitomized in the emergence of knowledge-based regional economies like California's Silicon Valley and the Research Triangle in North Carolina. We expect to see these agglomeration effects manifested in an inverse relationship between out-migration of the college-educated population and past growth of human capital.

\section{Empirical Results}

General observations. Table 6 summarizes the estimation results for the six lifecourse groups. Overall, the models of the propensity to leave an MSA perform quite well, with the log-likelihood ratio being significant for all groups. The model performs best for the Recent Alumnae, followed by their male counterparts.

Before discussing the group-specific valuation of QOL indicators, several observations can be made. First, consistent with other findings in the literature (Gottlieb and Joseph 2006; Hansen, Ban, and Huggins 2003), the migration propensity of persons living in their birth state is significantly smaller than the migration propensity of residents who were born in a different state. This finding holds over all life-course groups. However, the behavioral differences are quite substantial, in general, declining by age from a high of more than 11 percentage points for the recent graduates to a low of about 2.9 percentage points for the oldest.

Second, consistent with the literature on the age-dependency of migration (Pandit 1997; Rogers 1988), we find that migration propensities decline with increasing age up until the stage of retirement, and then the propensity reverses for the oldest group. However, it should be noted that the observed differences in migration rates across the six life-course groups are also influenced by other group-defining characteristics, particularly marital status and the presence of children. Moreover, the results also suggest that gender differences persist among recent graduates with men being slightly more likely to migrate than women.

Third, there is an almost universal tendency to stay in those metro areas that enjoy a growing human capital stock. This is an important result. It suggests that the agglomeration of human capital is a self-propelling process that - once set in motion - continues by dampening out-migration propensities of the college-educated. It also suggests that stopping the brain drain in metropolitan areas with slow or even negative human capital growth 


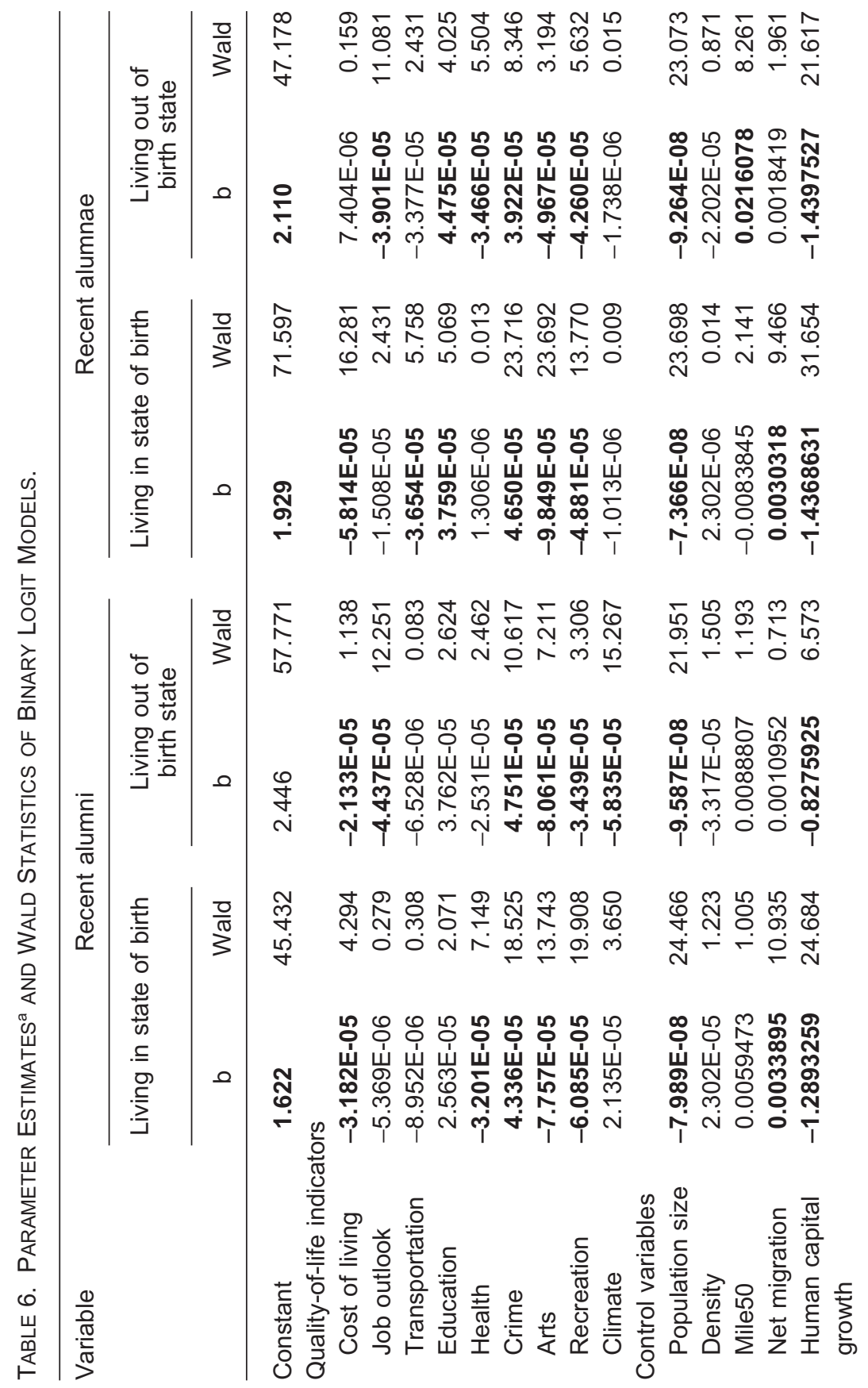




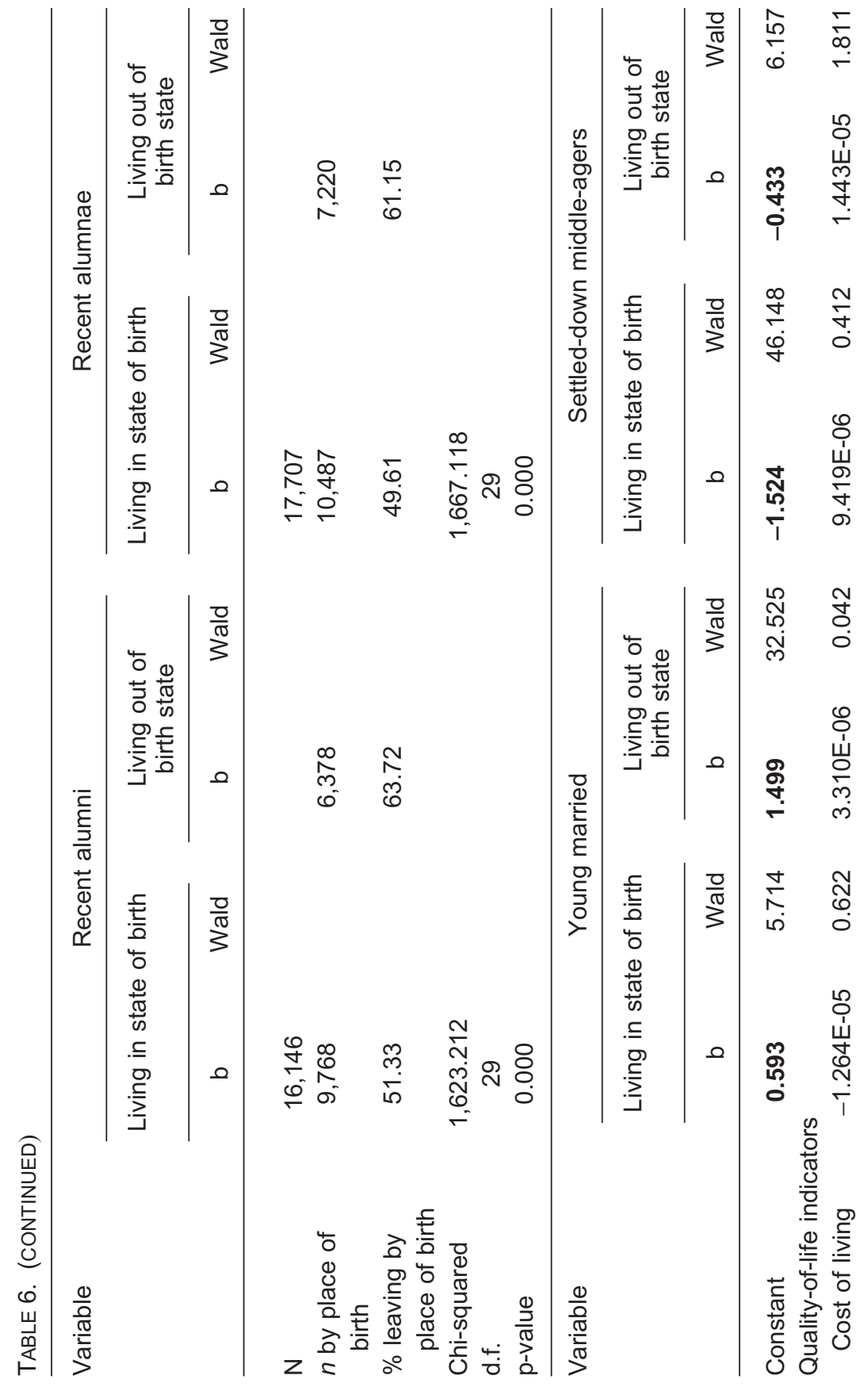




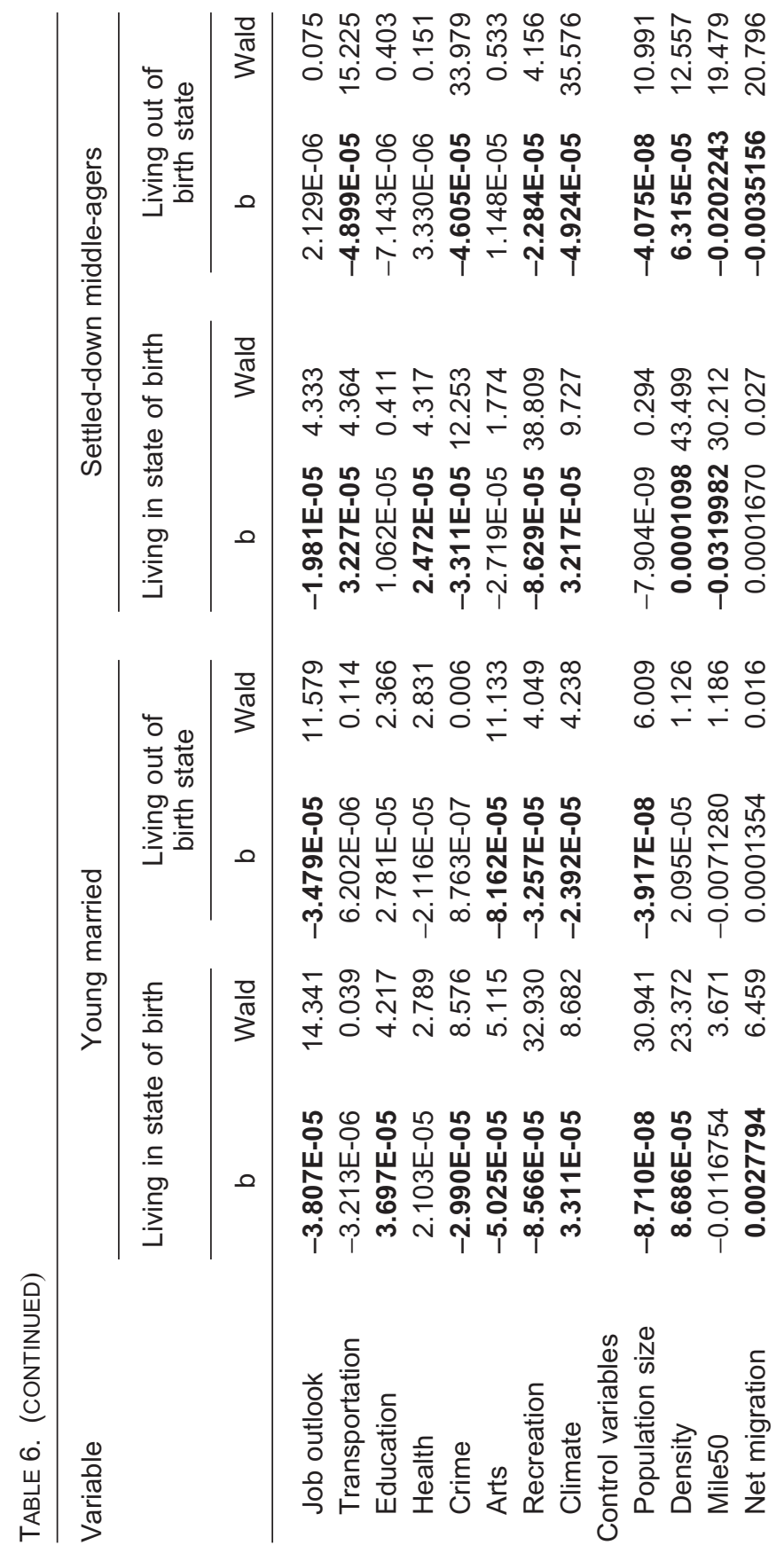




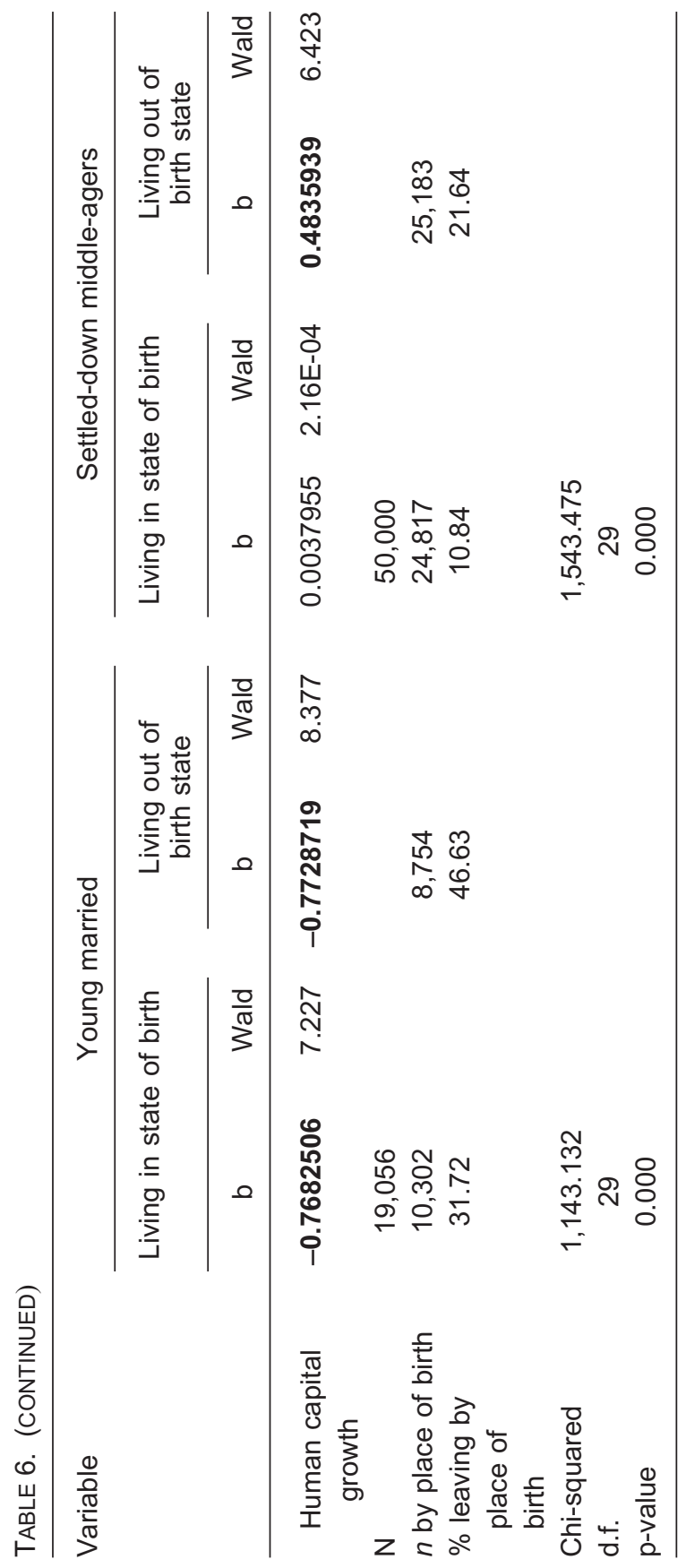




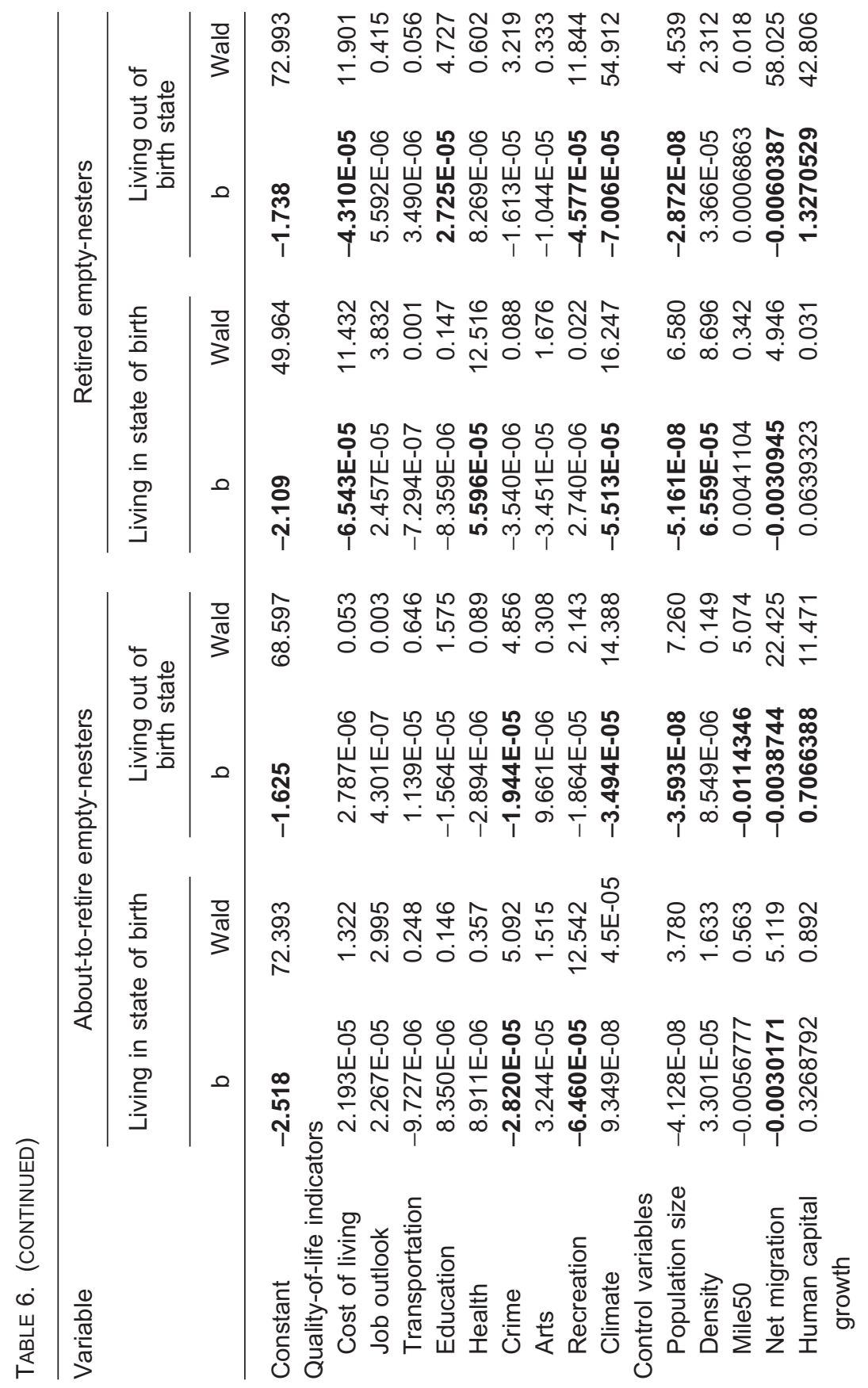




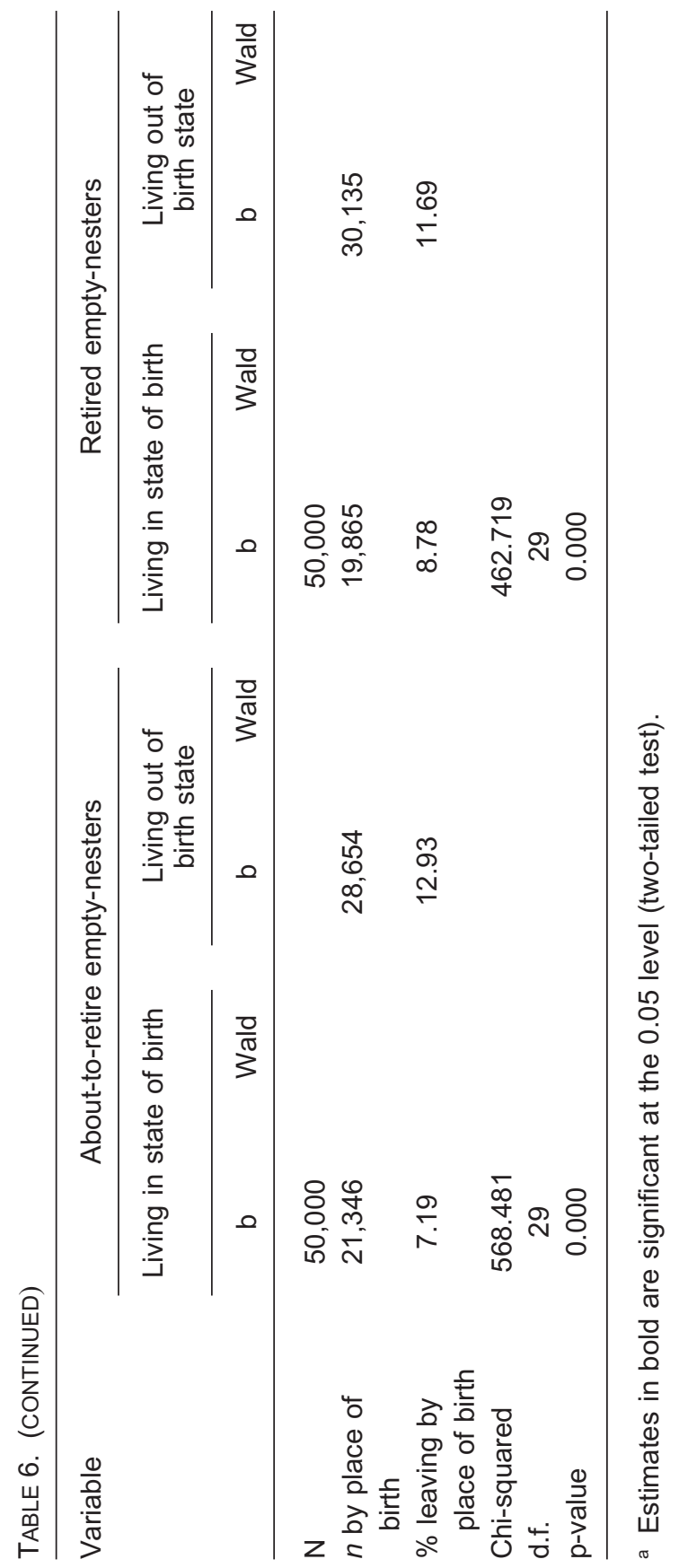


promises to be difficult because of the especially high out-migration rates exhibited by the college-educated.

Fourth, the groups differ with respect to city-size and density preferences. For persons born out-of-state, the migration propensity decreases with increasing population size. For persons born in the state of their 1995 residence, the big-city preference only holds for the younger age groups and the very old. With respect to density, young married couples, settled-down middle-agers, and those about-to-retire are more likely to leave from highdensity metro areas than from low-density metro areas. The migration behavior of the youngest and the oldest groups appears to be indifferent to density.

Fifth, we also find age differences with respect to net migration and proximity to other metro areas. As overall net migration rates increase, we find that the out-migration propensities increase for the younger but decrease for the older cohorts. The presence of other metro areas in close proximity has no effect on the migration propensities of the youngest and the oldest. Interestingly though, it dampens the migration propensities of the middleaged, who may substitute commuting for outright relocation.

Group-specific valuations of $Q O L$ indicators. Care should be taken in evaluating the role of amenities in the migration choices of college-leavers because their migration behavior is qualitatively different than the residential location choices made later in the life course. Students are generally considered "special populations" in that their moves are often viewed as fixed-period sojourns in a place. Out-migration from a college town does not necessarily imply leaving an "undesirable" place but instead choosing a workplace destination.

Given the mentioned caveat, our results suggest that recent graduates prefer to remain in affordable places. Their out-migration propensities generally increase with increasing cost of living. Interestingly, only for those born out-of-state does a poor job-outlook trigger out-migration. However, attributes appearing to be important to all young cohorts are recreational opportunities and a rich cultural environment. Metropolitan areas with low scores on the recreation and arts factors have higher out-migration rates than metropolitan areas that are well endowed with recreational opportunities and cultural activities. This is an important result that fits nicely into the debate about the economic development role of the "creative class" (Florida 2002a,b) and its preference for bohemian environments.

We find that recent graduates' propensity to leave a metropolitan area increases with decreasing crime rates. This contrasts with results obtained from a recent micro-level study that finds that high crime rates increase the hazard of migrating to another state (Huffman and Feridhanusetyawan 2007). However, our results are not implausible and do not imply that young graduates have a dislike for safe environments. Instead, we suspect that this life-course group has the financial means to locate in safe enclaves within metropolitan areas. Although there is evidence that high crime rates induce households to relocate (Cullen and Levitt 1999; Morenoff and Sampson 1997), Dugan (1999) suggests that the impact of crime rates on population turnover might in fact be quite localized, perhaps not extending beyond a one-mile radius around the crime scene. 
The results for the impact of transportation, education, health care, and climate indicators on the migration behavior of the recent graduates are mixed. Good transportation infrastructure lowers the migration propensities of young women residing in their birth state in 1995, but it is not a decisive criterion for male recent graduates. Good educational opportunities also do not play a role for young men and even increase the migration propensity of young women. This is not surprising given that this group has just completed its education and has now entered the labor force. Good health care infrastructure lowers the migration propensity or is insignificant. Finally, a good climate is - for the most part-irrelevant for the migration behavior of this group.

The results for young and childless married individuals show some similarities with those obtained for recent graduates. Young married couples also appear to strongly value rich recreation and arts amenities. However, we find them indifferent toward cost-of-living differentials. Presumably, because they are college-educated, have no children, and are (most likely working) spouses, they have sufficient disposable income to enjoy such amenities without worrying overly about high cost of living. They are, however, responsive to poor job prospects. The health and transportation infrastructures do not influence their migration behavior and rich educational opportunities do not play a role given that this group has completed their schooling. Those who were born out-of-state tend to be likely to leave from metro areas with harsh climate conditions and individuals who were born in their state of residence tend to have high out-migration rates from metropolitan areas with high crimes rates.

Aging and having children brings about drastic lifestyle changes. It is thus not surprising that the results for the settled-down middle-agers differ markedly from those of the younger and childless individuals. Not only do the settled-down middle-agers migrate substantially less (fewer than 13 percent of this group left their metro area between 1995 to 2000 compared to 30 percent or more for the younger groups) there is also a shift in preferences toward safety. For this group, out-migration propensities increase significantly with increasing crime rates. The results also suggest that settled-down middle-agers value rich recreational opportunities but are indifferent toward opportunities of higher education, an artsy environment, and cost of living. For those born in the state of their 1995 residence, a poor job outlook is a reason to leave, and for those born in another state, a poor climate is a strong trigger for out-migration.

The about-to-retire empty-nesters have the lowest overall out-migration propensity. Migration for this group is thus a somewhat unpredictable event and we suspect that many of the moves that do take place are made in anticipation of the upcoming retirement. Aside from a concern about safety - migration propensities increase with increasing crime rates-QOL indicators do not systematically influence the migration behavior of this group.

For the retired empty-nesters, we can safely assume that the moves are motivated by the new locational freedom associated with no longer being employed full-time. Our results show that retirees have a strong preference for a mild climate: they have a higher propensity to leave metro areas with unfavorable climates than those with a mild climate. Moreover, retirees - who often have to live on a reduced income - do care about affordability. Their 
propensity to leave a metropolitan area increases with increasing cost of living. Whereas cost of living is highest in the largest metropolitan areas, note that our multivariate findings show that, when costs are taken into account, the college-educated retirees have a lower propensity to leave from bigger compared to smaller metropolitan areas. This finding is of interest given the significant role currently being played by elderly migration in redistributing population downward within the U.S. metropolitan hierarchy (Plane, Henrie, and Perry 2005).

We cannot confirm the hypothesis that the migration propensities of the elderly are influenced by a metro area's health care opportunities. This unexpected result may be an artifact of the health indicator, which addresses barriers to health care rather crudely, using various physician-per-capita indicators. While such per capita indicators are commonly used in the health care literature, when applied at the wider metropolitan scale they do not account for health-worker disparities that can be quite extensive, both in inner-city areas and in the outlying counties of large metropolitan areas.

Ranking metropolitan areas. Applying the estimated parameters to U.S. metropolitan areas allows us to derive group-specific rankings based on out-migration rates. For each group, the metropolitan areas with the highest and lowest out-migration rates are listed in Table 7.

For the younger life-course groups, the set of metropolitan areas with the lowest out-migration rates includes the nation's biggest metropolitan areas. Many of those metro areas have previously been identified as favorable destinations of the young, single, and college-educated adults (Franklin 2003). This big-city bias is also confirmed in studies of the destination choice of college-to-work migrants (Gottlieb and Joseph 2006) and the locational choices of the so-called power couples (Costa and Kahn 2000) who are attracted to large urban areas with their abundance of managerial and professional jobs. On the other end of the scale, our estimates suggest very high rates of out-migration from small metro areas. Not surprisingly, these places include relatively small college towns such as Lafayette, Indiana (Purdue University), Bryan-College Station, Texas (Texas A\&M University), and State College, Pennsylvania (Pennsylvania State University). While offering excellent educational opportunities, these metro areas provide few employment opportunities for their college graduates. In combination, these results confirm the agglomeration of the young college-educated in a select group of urban centers.

The list of metro areas with low out-migration rates for the settled-down middle-agers includes a mixture of differently sized metropolitan areas, located in various regions of the country. A more distinct pattern is observable for the places with the highest out-migration rates. They include small- and medium-sized metro areas located outside the western United States. For the two oldest groups, the list of places with the lowest out-migration rates has a very distinct Sunbelt bias, including many metro areas located in California and Florida. Not surprisingly, places with a cold climate dominate the list of metropolitan areas with the highest out-migration rates.

Table 8 summarizes the correlations between the estimated group-specific out-migration rates. The coefficients are highly positive among the rates of the younger groups, thus 


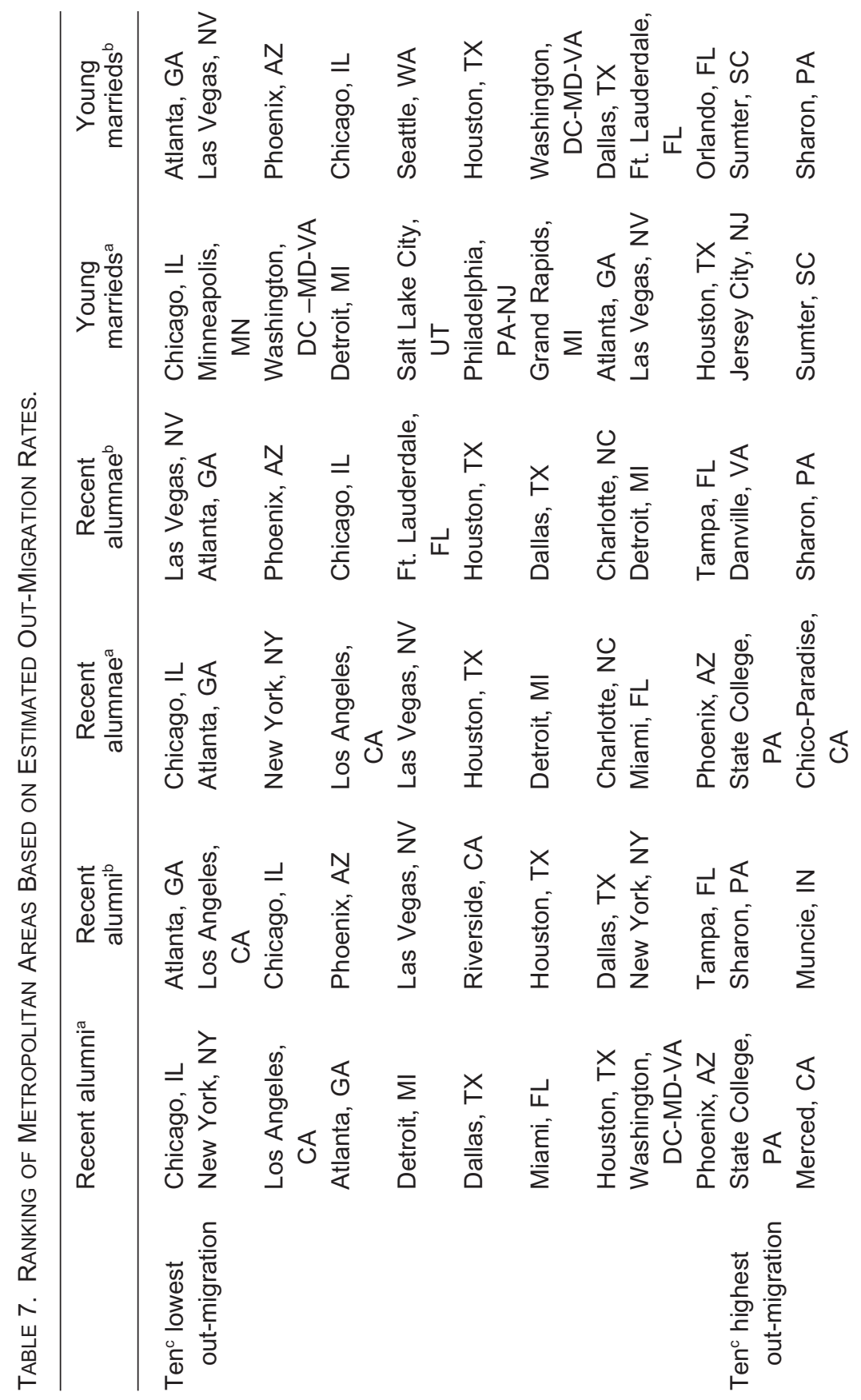




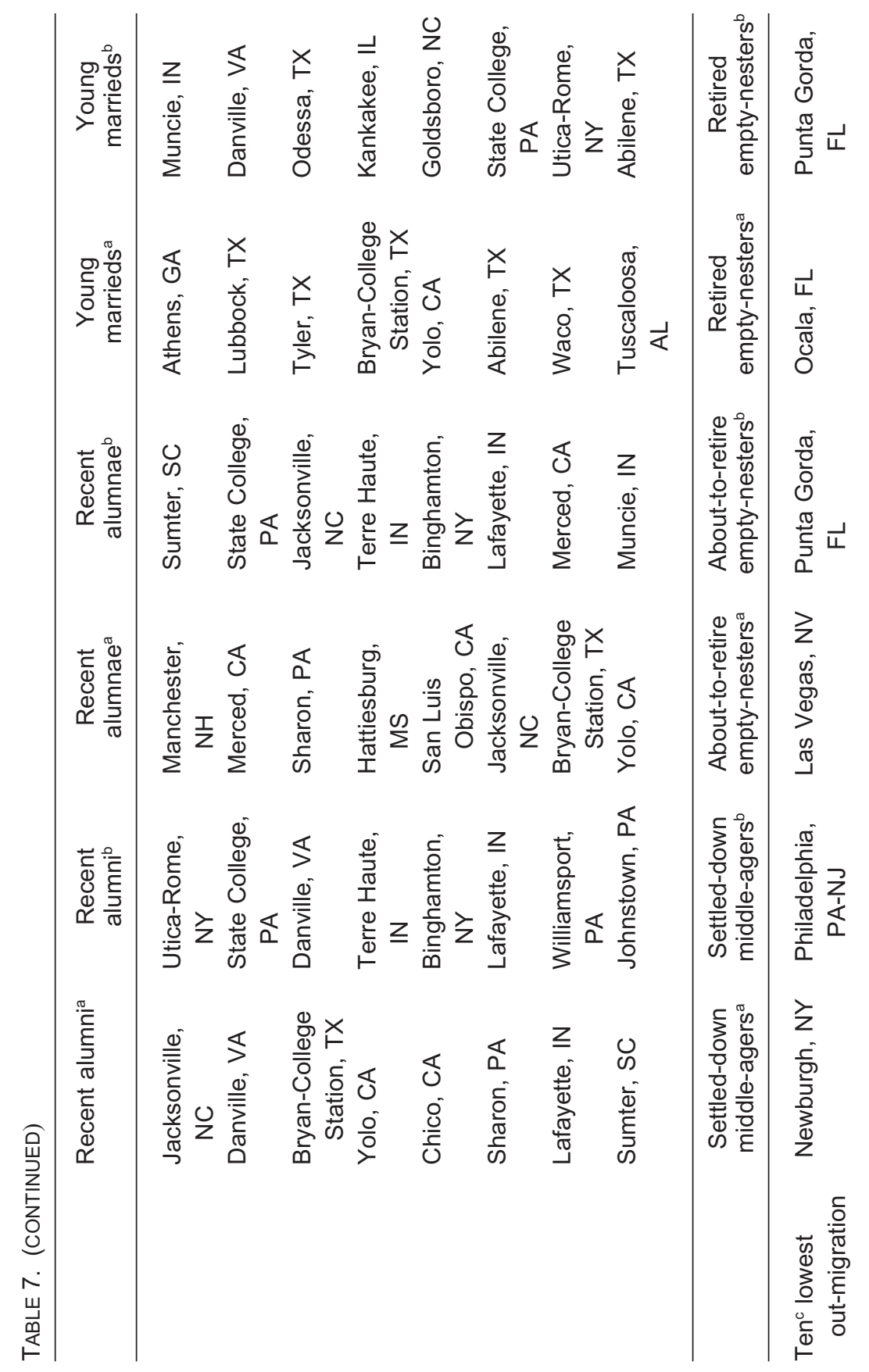




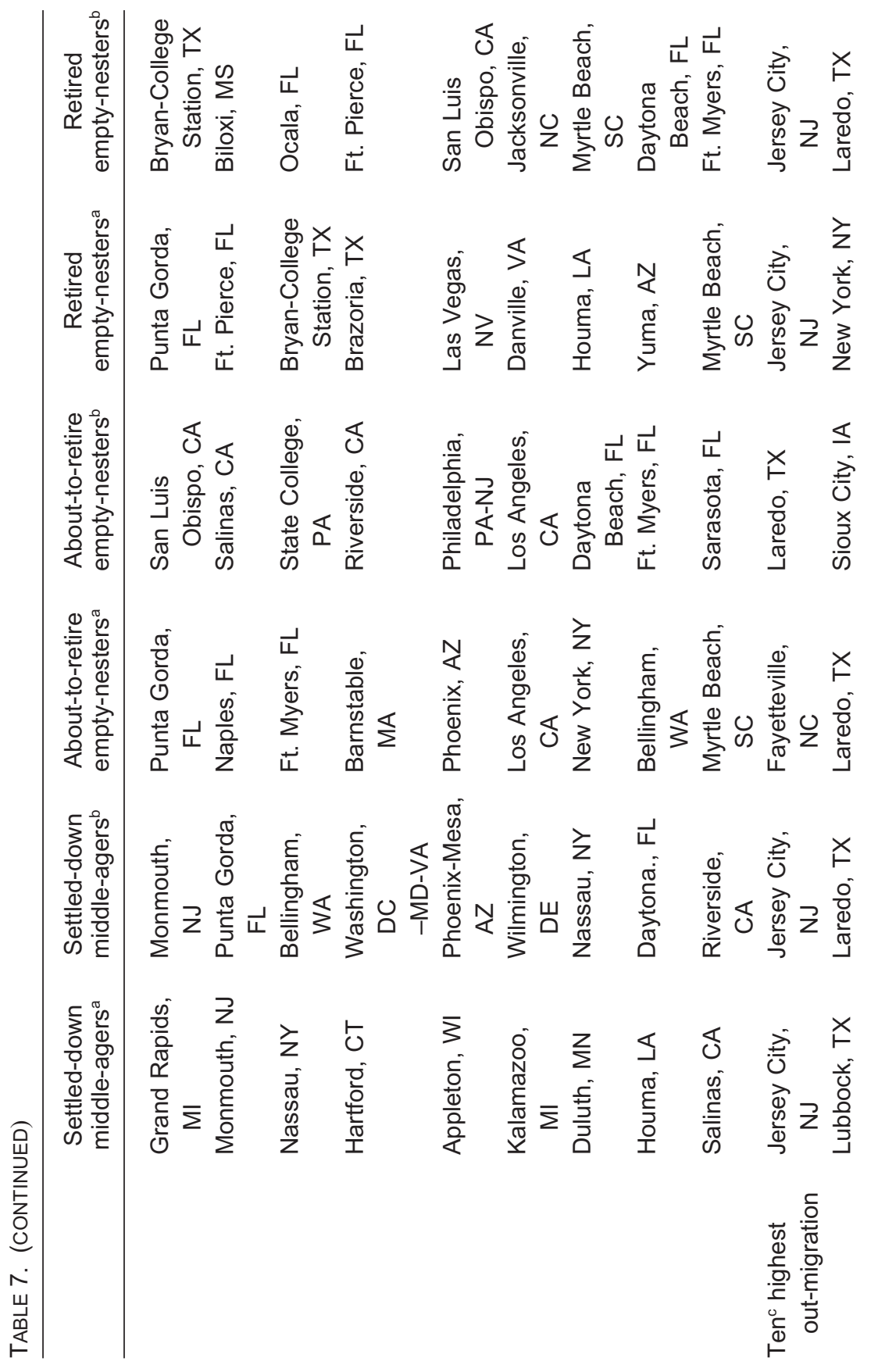




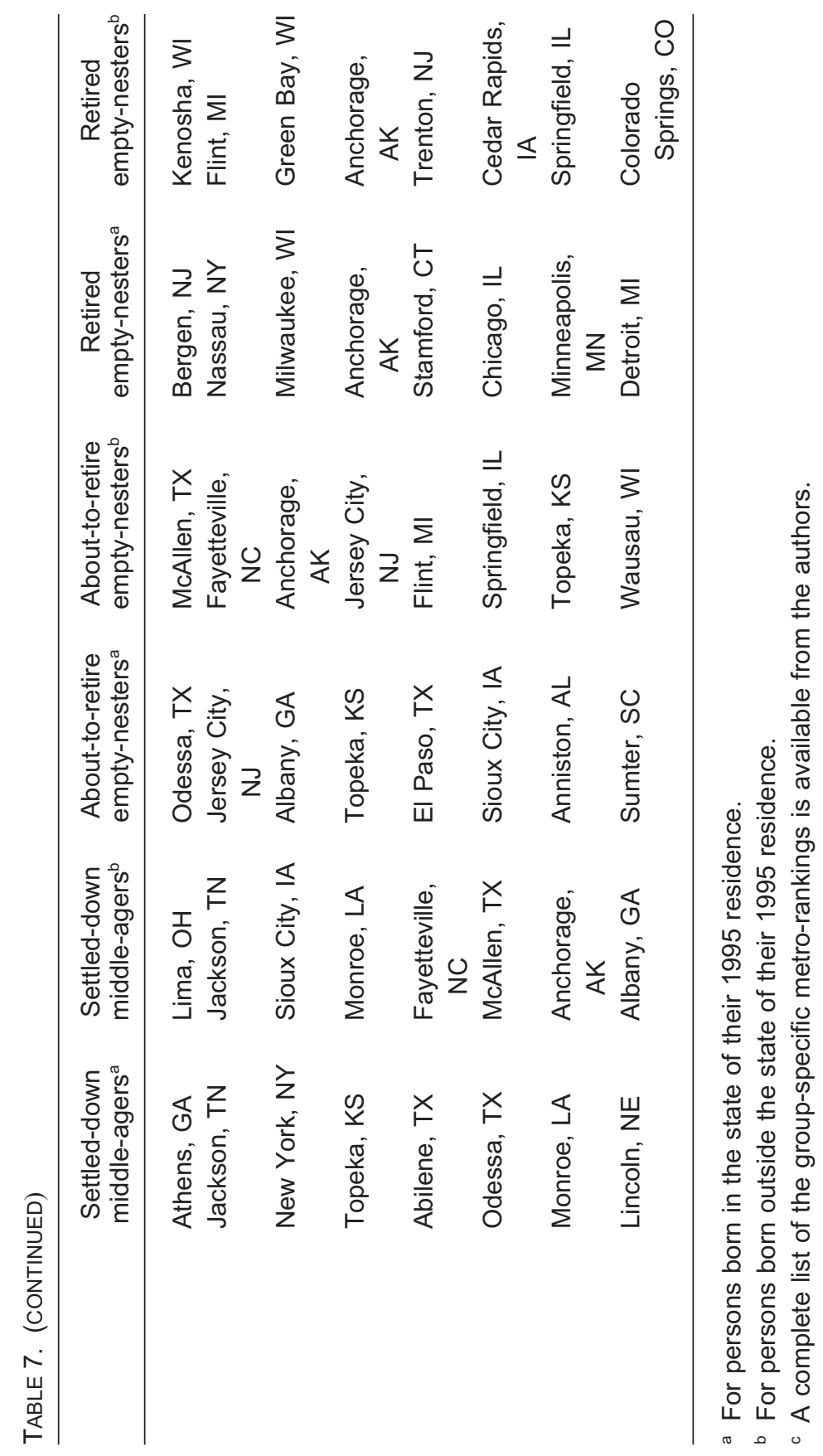




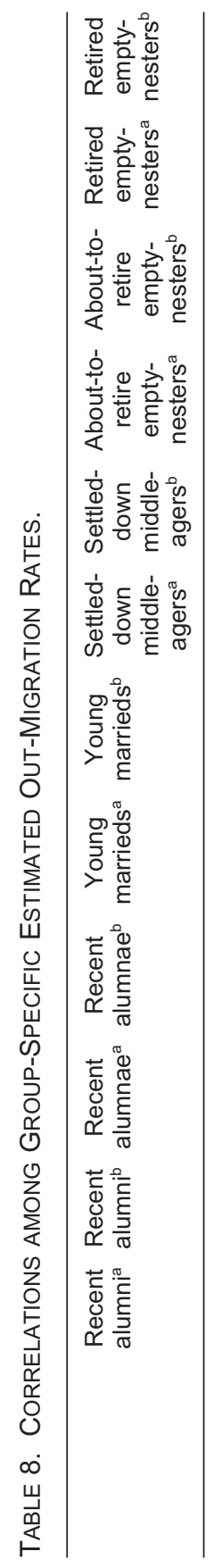

$$
\begin{aligned}
& \stackrel{8}{8} \\
& \begin{array}{ll}
\circ & 0 \\
\hdashline & 0 \\
\hdashline & 0
\end{array}
\end{aligned}
$$

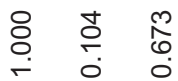

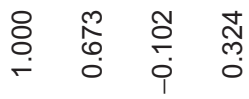

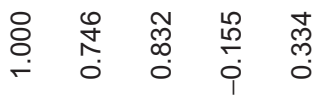

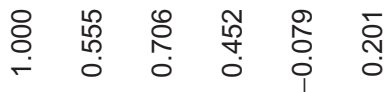

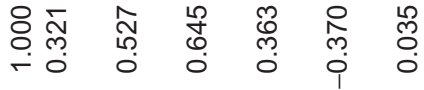

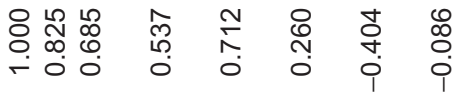

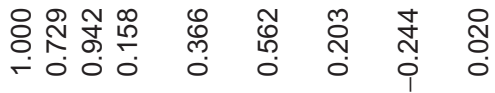

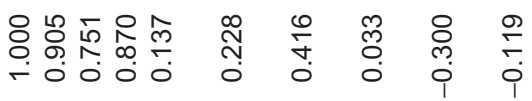

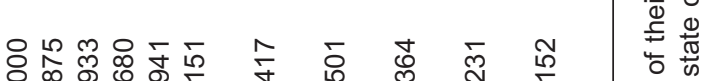

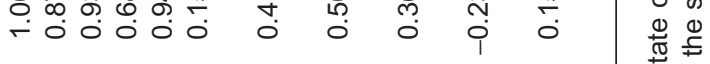

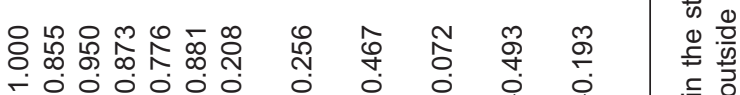

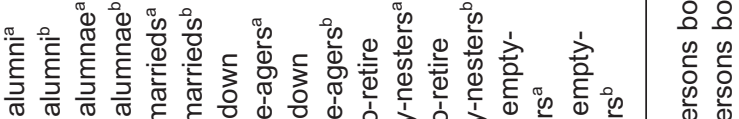

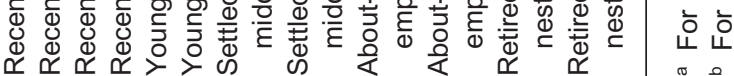

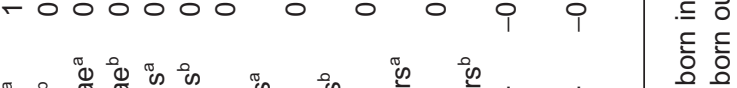

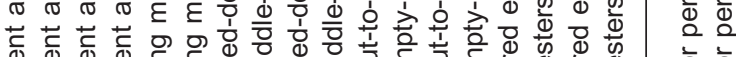


suggesting strong similarities of their out-migration behaviors. The rates of the settled-down middle-agers are positively - but only weakly to moderately strong — correlated with those of the younger cohorts. Finally, the correlations between the estimated out-migration rates of the older groups and the younger groups are weak, and in some cases even significantly negative. This clearly shows that the rankings of metropolitan areas are largely contingent on the life-course stage. Thus, the concept of "rating" places in terms of their overall residential desirability - at least desirability in the strict sense that these metropolitan areas are best able to retain their populations - makes very little sense as the retention power of urban places varies significantly across the different life-course groups.

\section{Summary and Conclusions}

Throughout history, migration-fueled population redistributions have characterized the demographics of the United States. The settlement of the West, the migration of AfricanAmericans to the North, the long-lasting rural population exodus of the twentieth century, and the recent migration of the elderly to the warmer climates of the South are just a few examples of such mass movements. Common to these diverse migration events is that they differentially involved segments of the population responding to specific attributes of their places of origin or destination.

This paper set out to explore how the college-educated population-segmented into selective demographic groups, from young adults to the elderly - differentially values QOL indicators of metropolitan areas. Among the noteworthy results, we find an almost universal preference for not leaving metropolitan areas with substantial human capital growth. Moreover, ceteris paribus, young graduates show a preference for big metropolitan areas, whereas families with children prefer lower-density settings. High cost of living particularly encourages migration of the very young and the very old. Those who are young and childless - whether married or unmarried - are very mobile in general, but have an especially high propensity to leave metropolitan areas that offer insufficient recreational opportunities and perform weakly in the arts. The large middle-aged life-course group leaves places with high crime rates and poor recreation amenities. Finally, retirees show a strong preference for leaving any metropolitan area with a high cost of living and an unfavorable climate. We thus conclude that - because the valuations of QOL indicators vary so greatly across the life course - an overall composite desirability index that rates the best and worst places is virtually meaningless. Instead, desirability indices pertaining to different lifecourse groups are more appropriate.

The study's focus on out-migration of the college-educated is important in that retention of an area's most educated population positively influences its competitive position. In light of shifting age distributions and an ever-growing share of the college-educated population, the results have important implications for the emergence of new migration patterns and the concentration of human capital. Our findings suggest that - after controlling for other spatial-demographic variables - human capital accumulation is a self-propelling process with high out-migration propensities of the college-educated population in metro areas with slow human capital growth. Thus, metropolitan areas that cannot, over a prolonged 
time, build an extensive college-educated workforce risks falling behind in today's knowledge economy. Our findings also provide important clues about tackling concerns about the (relative) loss of intellectual capital — concerns that have become ever so crucial in light of new threats to regions' competitiveness in knowledge-based economies (Gottlieb 2001; Waldorf 2006). This research suggests that investments in cultural activities and recreational opportunities could possibly payoff by reducing the loss of the young collegeeducated residents.

From a methodological perspective, it is important to draw attention to two issues. First, micro data are now widely used in migration research. Because personal characteristics are included, these data sets are very powerful. However, there has been little work analyzing how migration responses to QOL characteristics vary across stages of the life course using micro data. If constraints are not imposed by the size of the data set, this study has demonstrated the utility of allowing for variations in parameters through sample stratification.

Second, as in the Herzog and Schlottmann study, we focused solely on modeling out-migration. In other migration research, much attention has been devoted to QOL measures as determinants of the destination choice (Gottlieb and Joseph 2006). The relationship between in- and out-migration behavior, and the relationship of both migration rates to the attractiveness of places, has been the topic of earlier research (Plane, Rogerson, and Rosen 1984). Whereas in-migration has been found to be monotonically related to economic variables and other measures of desirability, a more U-shaped relationship appears to characterize out-migration. Places with relatively healthy economies may not only have high in-migration but also high out-migration. That is, people tend to move to, and from, positions of economic strength, resulting in positive correlations between in- and out-migration rates. Thus, care should be used in interpreting high rates of out-migration (as, e.g., in the case of college towns) as being indicative of low levels of residential desirability. Similarly, places with the lowest rates of out-migration may not be the most desirable as highly attractive places can be expected to have high rates of turnover. Our models controlled for some such intervening factors of the spatial-demographic context. Nevertheless, future work needs to more explicitly connect the in- and out-migration effects of QOL measures to get a more accurate picture of the impact of place characteristics on the migration behavior of the well-educated as they pass through the life course.

\section{NOTES}

1. The Dallas, Texas MSA and Fort Worth, Texas MSA were combined in the Herzog and Schlottmann (1986) study but were analyzed separately in our updated model.

2. Because of mismatches between the geographic boundaries of 1999 MSAs and the Public-Use Microdata Areas of Census 2000, 291 of the 331 MSAs defined by the Office of Management and Budget in 1999 are used in this study.

3. The groups represent some possible manifestations of the different life paths individuals follow. By no means do the six groups constitute an "all-inclusive" segmentation of the entire college-educated population. 
4. The models do not include race. Given the new race definitions used for Census 2000, identifying race groups has become much more detailed and complex, limiting potential comparability to the Herzog and Schlottmann (1986) results. Moreover, given that each group is homogenous with respect to higher-education level, labor force status, marital status, age, and presence of children, racial distinctions are of lesser importance than in the Herzog and Schlottmann study.

5. Although income has long been a key indicator influencing migration propensities, it is not used for the segmentation or in the model specification. The income variable of the PUMS data is quite problematic because it refers to the year 1999 rather than the time of the move. Moreover, it is top-coded, and thus, cannot adequately reflect the income variation of the often well-paid collegeeducated population. Interestingly, Herzog and Schlottmann (1986) also did not include income.

6. The long form of the U.S. Census does not ask specifically about migration, but asks about residential location at the time of the census and five years prior. Using this locational information to deduce migration behavior has some well-known problems, such as multiple moves during the five-year period.

7. Landis and Sawicki (1988) argue that many types of quality of place issues profiled in the Places Rated Almanac do not match the QOL issues that most concern local residents. They argue that the data are of little use to planners because it does not monitor the smaller geographies within metropolitan areas.

8. For particular life-course groups, the positive correlation may not hold. For example, when correlating the in- and out-migration rates for highly educated young singles in metro areas, the correlation coefficient is even slightly negative $(r=-0.15$, based on data taken from special tabulations of the U.S. Census Bureau: Census 2000 PHC-T-34: Migration for the Young, Single, and College-Educated for the United States, Regions, States, and Metropolitan Areas: 2000).

\section{REFERENCES}

Adamson, D.W., D.E. Clark, and M.D. Partridge. 2004. Do urban agglomeration effects and household amenities have a skill bias? Journal or Regional Science 44(2): 201-223.

Basker, E. 2002. Education, job search and migration. University of Missouri-Columbia Working Paper 02-16. http://papers.ssrn.com/sol3/papers.cfm?abstract_id=371120\#PaperDownload (accessed June 9, 2006).

Beale, C. 1969. The relationship of gross outmigration rates to net migration. Paper presented at the annual meeting of the Population Association of America, Atlantic City, NJ, April 10-12.

Becker, G.S. 1993. Human capital, 3rd ed.. Chicago, IL: University of Chicago Press.

Bell, D. 1973. The coming of post-industrial society. New York: Basic Books.

Berry, B.J.L., and F.E. Horton. 1970. Geographic perspectives on urban systems. Englewood Cliffs, NJ: Prentice-Hall.

Bloomquist, G.C., M.C. Berger, and J.P. Hoehn. 1988. New estimates of quality of life in urban areas. American Economic Review 78(1): 89-107.

Borts, G., and J. Stein. 1964. Economic growth in a free market. New York: Columbia University Press.

Brown, L.A., and E.G. Moore. 1970. The intra-urban migration process: A perspective. Geografiska Annaler 52B 1-13.

Carruthers, J.I., and B. Mundy, eds. 2006. Environmental valuation. Aldershot: Ashgate.

Clark, D., and W. Hunter. 1992. The impact of economic opportunity, amenities and fiscal factors on age-specific migration rates. Journal of Regional Science 32: 349-365. 


\section{GROWTH AND CHANGE, MARCH 2008}

Clark, D., T. Knapp, and N. White. 1996. Personal and location-specific characteristics and elderly interstate migration. Growth and Change 27: 327-351.

Clark, T., R. Lloyd, K. Wong, and P Jain. 2002. Amenities drive urban growth. Journal of Urban Affairs 24(5): 493-515.

Costa, D., and M. Kahn. 2000. Power couples: Changes in the locational choice of the college educated, 1940-1990. The Quarterly Journal of Economics 115(4): 1287-1315.

Cullen, J., and S. Levitt. 1999. Crime, urban flight, and the consequences for cities. The Review of Economics and Statistics 81: 159-169.

Cushing, B. 1993. The effect of the social welfare system on metropolitan migration in the US, by income group, gender and family structure. Urban Studies 30: 325-338.

Diamond, D.B., and G.S. Tolley, eds. 1982. The economics of urban amenities. New York: Academic Press.

Dissart, J.-C., and S.C. Deller. 2000. Quality of life in the planning literature. Journal of Planning Literature 1: 36-61.

Dugan, L. 1999. The Effect of victimization on a household's moving decision. Criminology 37 : 903-931.

Florida, R. 2002a. Bohemia and economic geography. Journal of Economic Geography 2: 5571.

2002b. The rise of the creative class. New York: Basic Books.

Franklin, R. 2003. Migration of the young, single, and college educated: 1995 to 2000. Census 2000 Special Reports 1-11

Glaeser, E., J. Kolko, and A. Saiz. 2000. Consumer city. NBER Working Paper Series 7790.

Glaeser, E.L. 1999. Are cities dying? Journal of Economic Perspectives 12: 139-160.

Gleave, D., and M. Cordey-Hayes. 1977. Migration dynamics and labor market turnover. In Progress in planning, Vol. 8, part 1, ed.. D. Diamond, and J. McLoughlin, 1-95. Oxford: Pergamon.

Golledge, R.G., and R.J. Stimson. 1997. Spatial behavior: A geographic perspective. New York: The Guilford Press.

Gottlieb, P.D. 2001. The problem of Brain Drain in Ohio and Northeastern Ohio. What is it? How sever is it? What should we do about it? Center for Regional Economic Issues. Case Western Reserve University.

Gottlieb, P.D., and G. Joseph. 2006. College-to-work migration of technology graduates and holders of doctorates within the United States. Journal of Regional Science 46(4): 627-649.

Graves, P. 1979. A life-cycle empirical analysis of migration and climate, by race. Journal of Urban Economics 6: 135-147.

- 1980. Migration and climate. Journal of Regional Science 20: 227-237.

1983. Migration with a composite amenity: The role of rents. Journal of Regional Science 23: 541-546.

Graves, P., and P. Linneman. 1979. Household migration: Theoretical and empirical results. Journal of Urban Economics 6: 383-404.

Greenwood, M.J. 1973. Urban economic growth and migration: Their interaction. Environment and Behavior A 5: 91-112.

1975. Research on migration in the United States: A survey. Journal of Economic Literature 13: 397-433. 
Greenwood, M.J., G.L. Hunt, D.S. Rickman, and G.I. Treyz. 1991. Migration, regional equilibrium, and the estimation of compensating differentials. American Economic Review 81: 1382-1390.

Greenwood, M.J., P.R. Mueser, D.A. Plane, and A.M. Schlottmann. 1991. New directions in migration research: Perspectives from some North American regional science disciplines. Annals of Regional Science 25: 237-270.

Gyourko, J., and J. Tracy. 1991. The structure of local public finance and the quality of life. Journal of Political Economy 99: 774-806.

Hansen, S., C. Ban, and L. Huggins. 2003. Explaining the "brain Ddain" from older industrial cities: The Pittsburgh Region. Economic Development Quarterly 17: 132-147.

Herzog, H., and A. Schlottmann. 1986. The metro rating game: What can be learned from recent migrants? Growth and Change 17: 37-50.

Huffman, W.E., and T. Feridhanusetyawan. 2007. Migration, fixed costs, and location-specific amenities: A hazard analysis for a panel of males. American Journal of Agricultural Economics 89(2): 368-382.

Isserman, A.M. 1986. Population change and the economy: Social science theories and models. Boston, MA: Kluwer Academic Publishers.

Jürges, H. 2006. Gender ideology, division of housework, and the geographic mobility of families. Review of Economics of the Household 4(4): 299-323.

Kodrzycki, Y. 2001. Migration of recent college graduates: Evidence from the National Longitudinal Survey of Youth. New England Economic Review 2001: 13-34.

Landis, J., and D. Sawicki. 1988. A planner's guide to the Places Rated Almanac. Journal of the American Planning Association 54: 336-346.

Levinson, D. 1978. The seasons of a man's life. New York: Knopf.

Lowry, I. 1966. Migration and metropolitan growth: Two analytical models. San Francisco, CA: Chandler.

Mathur, V. 1999. Human capital-based strategy for regional economic development. Economic Development Quarterly 13(4): 203-221.

Mincer, J. 1978. Family migration decisions. Journal of Political Economy 86: 749-773.

Morenoff, J., and R. Sampson. 1997. Violent crime and the spatial dynamics of neighborhood transition: Chicago, 1970-1990. Social Forces 76: 31-64.

Mueser, P., and P. Graves. 1995. Examining the role of economic opportunity and amenities in explaining population redistribution. Journal of Urban Economics 37: 176-200.

Mulligan, G., J. Carruthers, and M. Cahill. 2004. Urban quality of life and public policy: A survey. In Urban dynamics and growth 266, ed.. R. Capello and P. Nijkamp, 729-802. North Holland, The Netherlands: Elsevier.

Nivalainen, S. 2004. Determinants of family migration: Short moves vs. long moves. Journal of Population Economics 17(1): 157-175.

Pandit, K. 1997. Cohort and period effects in U.S. migration: How demographic and economic cycles influence the migration schedule. Annals of the Association of American Geographers 87(3): 439-450.

Plane, D., and F. Heins. 2003. Age articulation of U.S. inter-metropolitan migration flows. Annals of Regional Science 37: 107-130. 


\section{GROWTH AND CHANGE, MARCH 2008}

Plane, D., C. Henrie, and M. Perry. 2005. Migration up and down the urban hierarchy and across the life course. Proceedings of the National Academy of Sciences 102: 15313-15318.

Plane, D., P. Rogerson, and A. Rosen. 1984. The cross-regional variation of in-migration and outmigration. Geographical Analysis 16: 162-175.

Porell, F. 1982. Intermetropolitan migration and quality of life. Journal of Regional Science 22: $137-158$.

Rappaport, J. 2003. Moving to nice weather. RWP 03-07. Federal Reserve Bank of Kansas City.

- 2007. Moving to high quality of life. RWP 07-02. Federal Reserve Bank of Kansas City.

Roback, J. 1982. Wages, rents, and the quality of life. The Journal of Political Economy 90(6): 1257-1278.

Rogers, A. 1988. Age patterns of elderly migration: An international comparison. Demography 25(3): 355-370.

Rosen, S. 1974. Hedonic prices and implicit markets: Product differentiation in pure competition. Journal of Political Economy 98: 1655-1666.

Rossi, P.H. 1955. Why families move: A study in the social psychology of urban residential mobility. Glencoe, IL: Free Press.

Rowland, D.T. 1982. Living arrangements and the later family cycle in Australia. Australian Journal of Ageing 1: 3-6.

Savageau, D., and G. Loftus. 1997. Places Rated Almanac, 5th ed. New York: Simon Schuster, Inc. Schaeffer, P. 1987. A family model of migration. Socio-Economic Planning Sciences 21: 263-226.

Scott, A.J., ed.. 2001. Global city-regions: Trends, theory, policy. Oxford: Oxford University Press.

Sjaastad, L. 1962. The costs and returns of human migration. Journal of Political Economy 70(Suppl.): 80-93.

Smith, D.M. 1977. Human geography: A welfare approach. London: Edward Arnold.

Swain, L., and S. Garasky. 2007. Migration decisions of dual-earner families: An application of multilevel modeling. Journal of Family and Economic Issues 28(1): 171-182.

Thirlwall, A.P. 1966. Migration and regional unemployment. Westminster Bank Review (November): $31-44$.

Wakabayashi, M., and G.J.D. Hewings. 2007. Life-cycle changes in consumption behavior: Agespecific and regional variations. Journal of Regional Science 47: 315-337.

Waldorf, B. 2006. Indiana's knowledge corridor. Research Report, Purdue Center for Regional Development, PCRD-R-1. http://www.ces.purdue.edu/extbusiness/pcrd/PCRD-R-1LR.pdf (accessed August 3, 2006).

2007. Brain drain in rural America. Selected Paper, Annual Meetings of the Association of Agricultural Economics, Portland, OR, July 2007. http://agecon.lib.umn.edu/cgi-bin/pdf_view.pl? paperid $=26383 \&$ ftype $=$.pdf (accessed July 7, 2007).

Welch, R., J. Carruthers, and B. Waldorf. 2007. Public service expenditures as compensating differentials in United States Metropolitan Areas: Housing values and rents. Cityscape: A Journal of Policy Development and Research 9(1): 131-156.

Wilkinson, B., 2007. Leaving Los Angeles: Education and migration in the late-capitalist context. MA Thesis, University of Arizona.

Wolpert, J. 1965. Behavioral aspects of the decision to migrate. Papers of the Regional Science Association 15: 159-169. 